\title{
Tedarik Zinciri Yönetiminde Sürdürülebilirlik Uygulamaları ve Malatya İli Örneği ${ }^{1}$
}

\author{
Sustainability Practices in Supply Chain Management And Malatya City Example
}

\section{Salih GÜLTEKIN}

Blm. Uzm., İnönü Üniversitesi,

SBE, slhgultekin@gmail.com

https://orcid.org/0000-0002-9371-4111
Makale Başvuru Tarihi: 28.06.2021

Makale Kabul Tarihi: 16.08 .2021

Makale Türü: Araştırma Makalesi

\author{
Mustafa DESTE \\ Dr. Öğr. Üyesi, İönü Üniversitesi, İ̈BF, \\ İşletme Bölümü, mustafa.deste@inonu.edu..tr \\ https://orcid.org/0000-0001-5781-6543
}

\section{Anahtar Kelimeler: \\ Tedarik Zinciri \\ Yönetimi, \\ Sürdürülebilir \\ Tedarik Zinciri \\ Yönetimi,}

Sürdürülebilirlik,

Sürdürülebilir

Üretim,

Yeşil Tedarik,

\section{Keywords: \\ Supply Chain \\ Management,}

Sustainable Supply

Chain Management,

Sustainability,

Sustainable

Production,

Green Supply,

\section{ÖZET}

Tedarik zinciri yönetimi kapsamında, sürdürülebilirliğin üç boyutu olan ekonomik, çevresel ve sosyal sürdürülebilirlik başlıklarının kapsaml olarak ele alındığ bu çalışmada; Malatya ili organize sanayilerinde faaliyet gösteren işletmeler üzerine bir araştırma yapılmışıtır. Yapılan bu araştırma ile son yıllarda önemi hızla artan "sürdürülebilirlik" kavramını, tedarik zinciri yönetimi bağlamında ele alarak, literatüre katkı sağlanması amaçlanmıştır. Bu amaç doğrultusunda, çalışma kapsamındaki işletmelerin, sürdürülebilir tedarik zinciri yönetimi konusundaki engel ve algılarının ölçülmesine, engel ve algl düzeylerinin işletmelerin temel bazı özelliklerine göre dağılımında farklılık olup olmadığının tespit edilmesine çalışılmıştır. Ayrıca bu çalışmada, işletmelerin sürdürülebilir tedarik zinciri yönetimi algl ve engel düzeylerinin, işletmelerin; ekonomik, çevresel ve sosyal sürdürülebilirlik performansları ile olan ilişkisi incelenmiştir. Son olarak araştırma konusu işletmelerin; ekonomik, çevresel ve sosyal sürdürülebilirlik performansları arasındaki ilişki analiz edilmiştir. Bu çerçevede çalışmanın, hem değerlendirme ve çözüm önerileri için kullanılmasına hem de Malatya ili organize sanayi bölgelerinde faaliyet gösteren işletmelerin sürdürülebilirlik yaklaşımlarını ortaya koyabilecek bir envanter oluşturulmasına katkı sağlayacağını ifade etmek mümkündür.

\section{ABSTRACT}

Within the scope of supply chain management, in this study, the three dimensions of sustainability, namely economic, environmental and social sustainability, are comprehensively discussed; a research was conducted on the enterprises operating in the organized industries of Malatya province. With this research, it is aimed to contribute to the literature by considering the concept of "sustainability", whose importance has increased rapidly in recent years, in the context of supply chain management. For this purpose, within the scope of the study, it was tried to measure the obstacles and perceptions of the enterprises about sustainable supply chain management, and to determine whether there is a difference in the distribution of the barriers and perception levels according to some basic characteristics of the enterprises. In addition, in this study, the relationship between the sustainable supply chain management perception and barrier levels of enterprises and their economic, environmental and social sustainability performances were examined. Finally, the relationship between the economic, environmental and social sustainability performances of the research subjects companies was analyzed. In this context, it is possible to state that the study will contribute to both the use of evaluation and solution suggestions and the creation of an inventory that can reveal the sustainability approaches of the enterprises operating in the organized industrial zones of Malatya.

1 Bu makale, Salih GÜLTEKIN (1. Yazar) tarafindan 2021 yılında Dr. Öğr. Üyesi. Mustafa DESTE (2. Yazar) danışmanlığında hazırlanarak İnönü Üniversitesi Sosyal Bilimler Enstitüsünce kabul edilen "Tedarik Zinciri Yönetiminde Sürdürülebilirlik Uygulamaları ve Malatya İli Örneği” başlıklı yüksek lisans tezinden elde edilmiştir. 


\section{GIRISS}

İşletmelerin üretmiş oldukları mal veya hizmetlerin, hammaddeden nihai kullanıcıya ulaşması ve satış sonrası hizmetlere kadar olan tüm süreçlerin yönetilmesi olarak ifade edilen, Tedarik Zinciri Yönetimi kavramının önemi son y1llarda giderek artmaktadır. Tedarik zinciri yönetimi, "hammadde temini yapan, onları ara mal ve nihai ürüne çeviren ve nihai ürünleri müssterilere dağıtan, üretici ve dağıtıcıların oluşturduğu bir ă̆", şeklinde tanımlanmaktadır (Lee ve Billington, 1992:66). İşletmelerin rekabet gücünü önemli ölçüde etkileyen bu kavram, hızla artan küreselleşme, hızlı nüfus artışı, ürün ve hizmet çeşitliliğinde meydana gelen artışlar gibi nedenlerle birlikte işletmelerin hatta ülkelerin gündeminde daha sık yer almaktadır.

Uluslararası ticaretin artması, pek çok ülkenin bütçesini geride bırakan çok uluslu şirketlerin faaliyet alanlarının genişlemesi, işletmeler ve ülkeler için tedarik zinciri yönetiminin öneminin giderek artmasına neden olmaktadır. Ayrıca, hızla artan üretim ve tüketimin beraberinde getirmiş olduğu; küresel çapta karbon salınımındaki artış, endüstriyel atıkların su kaynakları ve toprağın kirliliğine sebep olması, tehlikeli kimyasal madde kullanımın artışı gibi nedenlerle tedarik zinciri yönetiminin sürdürülebilirliği konusu gündeme gelmiştir. Dünyamız ve özelde işletmeler yukarıda bahsedilen nedenlerle oluşan çevresel problemlerin yanında, sosyal ve ekonomik sorunlarla da karşı karşıyadır. Bu sorunlardan hareketle son yıllarda tedarik zinciri yönetimi kavramı Sürdürülebilirlik bağlamında ele alınmaktadır.

Sürdürülebilir tedarik zinciri yönetimi, sürdürülebilir kalkınmanın üç boyutundan, yani ekonomik, çevresel ve sosyal hedefleri bütünleştirirken, tedarik zinciri boyunca şirketler arasındaki işbirliğinin yanı sıra, malzeme, bilgi ve sermaye akışlarının yönetimi olarak tanımlanmaktadır (Galal ve Abdul Moneim, 2016:419). Yeşil tasarım, envanter yönetimi, yeniden üretim için, üretim planlama ve kontrol, ürün geri kazanımı, ters lojistik, atık yönetimi, enerji kullanımı ve emisyonların azaltılması gibi konular sürdürülebilir tedarik zinciri yönetiminin odaklandığı diğer uygulamalardır (Zailani vd., 2012:331).

Bu çalışma ile Malatya ili Organize Sanayi Bölgelerinde faaliyet gösteren işletmelerin, sürdürülebilir tedarik zinciri yönetimi konusundaki engel ve algılarının tespit edilmesi, engel ve algı düzeylerinin işletmelerin temel bazı özelliklerine göre dağılımında farklılık olup olmadığının açıklanması amaçlanmıştır. Ayrıca katılımcı işletmelerin, sürdürülebilir tedarik zinciri yönetimi algı ve engel düzeylerinin, işletmelerin; ekonomik, çevresel ve sosyal sürdürülebilirlik performansları ile olan ilişkisi incelenmiştir. Son olarak araştırma konusu işletmelerin; ekonomik, çevresel ve sosyal sürdürülebilirlik performansları arasındaki ilişki incelenmiştir.

\section{KAVRAMSAL VE KURAMSAL AÇIDAN SÜRDÜRÜLEBİLİR TEDARIKK ZINCİRİ YÖNETIMİ}

Küresel 1sınma, hem doğal hem de yenilenemeyen kaynakların tükenmesi, gelişmiş ve gelişmekte olan ekonomilerde artan endüstriyel faaliyetler, hükümet kurumlarının ve kâr amacı gütmeyen kuruluşların, bu konulardaki endişeleri, çeşitli paydaşları sürdürülebilirliğe odaklanmaya zorlamıştır (Ageron vd., 2012:171). Bu bağlamda, işletmeler için hayati önem taşıyan tedarik zincirlerinin; ekonomik, çevresel ve sosyal açıdan sürdürülebilir olması, hem işletmelerin devamlılığı hem de üzerinde yaşadığımız dünya için kritik derecede öneme sahiptir.

\subsection{Sürdürülebilir Tedarik Zinciri Yönetimi ve Boyutları}

Birçok alanda meydana gelen çevre bilinci, kamuoyu baskıları ve yasal düzenlemelerin etkisiyle, şirketler; kirlilik düzeyi azaltılmış üretim sistemleri ortaya çıkarmak, atık seviyelerini düşürmek, çevresel riskleri yönetebilmek ve sosyal sorumluluk bilinciyle faaliyetlerini gerçekleştirmek üzere, tedarik zincirlerini, çevreye daha duyarlı bir yapı haline getirmekte ve sürdürülebilir tedarik zinciri yönetimini benimsemektedirler (Arı ve Ergin, 2018:11).

İşletmeler, fiyatlardaki dalgalanmalar ve iklim değişikliği gibi birbiriyle ilişkili çok sayıda ekonomik ve çevresel zorluğa yanıt olarak, tedarik zincirlerini incelemeye başlamışlardır. Çevrenin korunmasına duyulan ihtiyaç ve doğal kaynaklara duyulan artan talep, şirketleri iş modellerini yeniden gözden geçirmeye ve tedarik zinciri faaliyetlerini yeniden yapılandırmaya zorlamaktadır (Wu, 2011:577).

Wittstruck ve Teuteberg (2010), sürdürülebilir tedarik zinciri yönetiminin ana bileşenlerini ve onu tehdit eden riskleri, Şekil 1'de yer aldığı gibi, "Sürdürülebilir Tedarik Zinciri Yönetimi Evi" adıyla şematik bir şekilde ifade etmiştir (Wittstruck ve Teuteberg, 2010:143). 
Şekil 1'de ifade edildiği gibi, sürdürülebilirliğin farklı boyutları (ekonomik, çevresel, sosyal), sürdürülebilir tedarik zinciri yönetiminin güçlü üç dayanağını oluş̧ururken; risk ve uyumluluk yönetimleri, yasalar, standartlar ve düzenlemeler STZY'nin temelini oluşturur. Etkili bir sürdürülebilir tedarik zinciri yönetimi stratejisi, bilgi teknolojileri ile uyum ve yerleşik organizasyon kültürü, çevresel ve piyasa kaynaklı tehditlere karşı işletmeleri başarıyla koruyabilir.

Şekil 1. Sürdürülebilir Tedarik Zinciri Evi

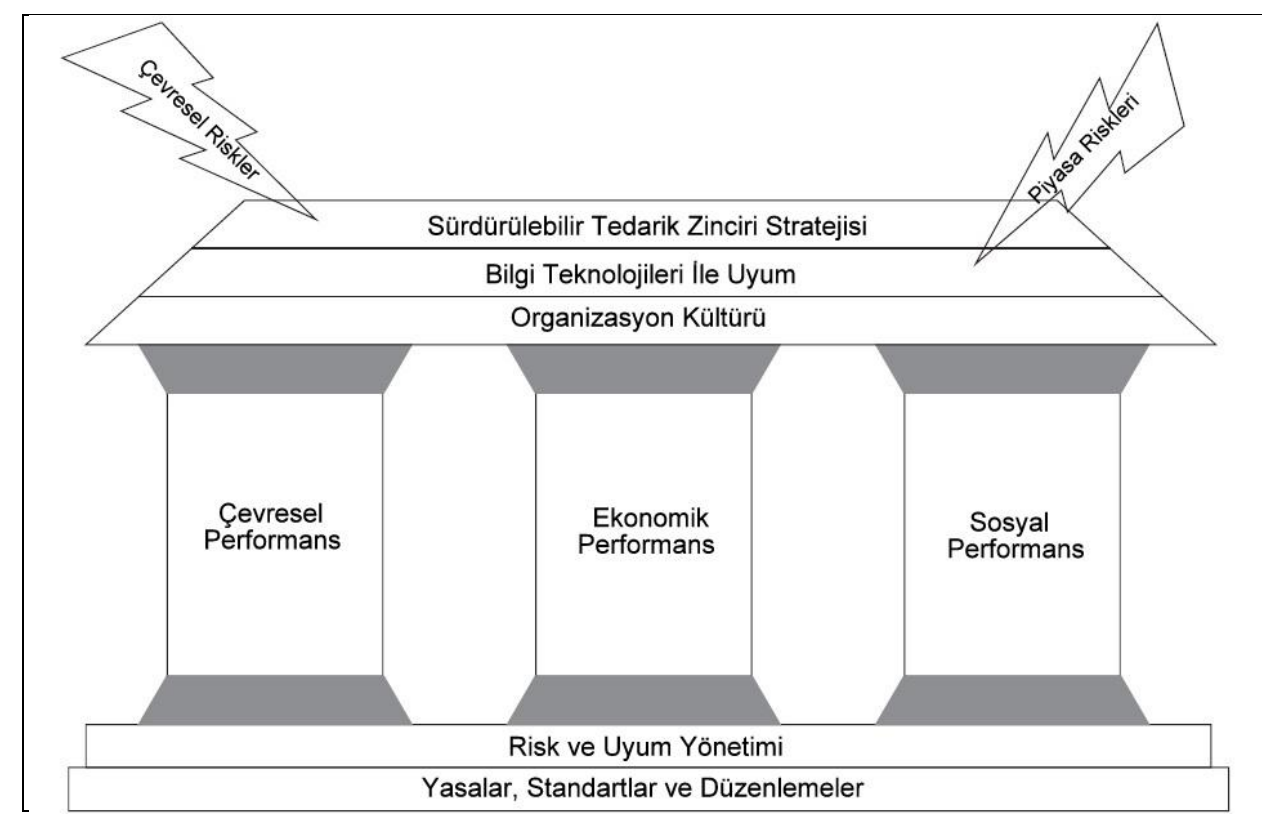

Kaynak: Wittstruck ve Teuteberg, 2010:143.

\subsubsection{Ekonomik Boyut}

İşletmeler için en önemli rekabet avantajlarından biri olan kârlılık veya ekonomik büyüme, iş süreçlerinin de sürdürülebilir olmasına katkı sağlamaktadır. Kalite, verimlilik, müşteri taleplerine hızlı cevap verebilme gibi faktörler kârlılıkla birlikte, ekonomiyi etkileyen diğer unsurlardır (Şişman vd., 2016:78). Ekonomik sürdürülebilirlik performansını artırmak için, tedarik zincirinin üyeleri, tedarikçileriyle var olan ilişkilerinin sürdürülebilirliğini sağlamalıdırlar. Böylece zincir katılımcısı olan işletmeler, hammadde ve yardımcı malzeme tedariki süreçlerinde sürdürülebilirlik standartlarını karşılayabilmede ve uygulamada devamlılığa ulaşabilir (Toker, 2017:307).

Tablo 1'de sürdürülebilirliğin ekonomik boyutları, fayda ve ölçüm kriterleri yer almaktadır.

Tablo 1. Ekonomik Boyutlar, Faydalar ve Ölçüm Örnekleri

\begin{tabular}{|c|l|l|}
\hline Ekonomik Boyut & \multicolumn{1}{|c|}{ Faydalar ve Sağlanan İyileşmeler } & \multicolumn{1}{c|}{ Ölçümler } \\
\hline Kalite & $\begin{array}{l}\text { Ürün ve hizmet kalitesinde artış Müşteri } \\
\text { hizmet seviyesi Kullanılabilirlik / } \\
\text { Uygunluk }\end{array}$ & $\begin{array}{l}\text { Stok diş1 kalma, müşteriye yanıt süresi, ürün gecikmesi, } \\
\text { zamanında teslimat, güvenli teslim, müşteri memnuniyeti, } \\
\text { müşterilerin şikâyetleri, ürün kullanılabilirliği. }\end{array}$ \\
\hline Etkinlik & $\begin{array}{l}\text { Verimliliğin sağlanması / Maliyetlerin } \\
\text { düşmesi }\end{array}$ & $\begin{array}{l}\text { Nakit akışı, stok seviyesi, toplam lojistik giderleri, katma } \\
\text { değer verimliliği, depo kullanımı, dönen varlıklar, teslimat } \\
\text { maliyeti }\end{array}$ \\
\hline $\begin{array}{c}\text { Müşteri Taleplerine } \\
\text { Yanıt Verebilirlik }\end{array}$ & $\begin{array}{l}\text { Müşteri taleplerinin karş1lanması / Pazar } \\
\text { değişimine yanıt / Esneklik }\end{array}$ & $\begin{array}{l}\text { Pazara giriş zamanı, üretim esnekliği, tüketiciye cevap süresi, } \\
\text { takip ve izleme performansı, siparişin esnekliği }\end{array}$ \\
\hline
\end{tabular}

Kaynak: Çetinkaya vd., 2011:61. 


\subsection{2. Çevresel Boyut}

Gelişmekte olan (veya yakın zamanda ortaya çıkan) pazarlarda, müşterilerden gelen taleplerin artması, doğal kaynakların korunmasına duyulan ihtiyaç ve yasal düzenlemeler, işletmeler ve tedarik zincirleri için, çevresel sorunları ve standartları hayati hale getirmiştir (Gopalakrishnan vd., 2012:196). Tablo 2'de sürdürülebilirliğin çevresel boyutlarının uygulamadaki kazanımları ve ölçüm kriterleri yer almaktadır.

Tablo 2. Çevresel Boyutlar, Faydalar ve Ölçüm Örnekleri

\begin{tabular}{|c|c|c|}
\hline Çevresel Boyut & Faydalar ve Sağlanan İyileşmeler & Ölçümler \\
\hline $\begin{array}{l}\text { Emisyonlar / } \\
\text { Salınımlar }\end{array}$ & $\begin{array}{l}\text { Salınan karbondioksit } \\
\text { Çevre kirliliğine neden olan diğer salınımlar }\end{array}$ & $\begin{array}{l}\text { Her litrede ortaya çıkan, harcanan karbondioksit oranı, toplam } \\
\text { karbondioksit salınımı, azalan karbondioksit salınım oranı }\end{array}$ \\
\hline $\begin{array}{c}\text { Doğal Kaynak } \\
\text { Kullanımı }\end{array}$ & $\begin{array}{l}\text { Tüketilen yakıt miktarı } \\
\text { Tüketilen su miktarı } \\
\text { Arsa kullanım miktarı } \\
\text { Tüketilen enerji miktarı }\end{array}$ & $\begin{array}{l}\text { Yakıt tüketiminin azalması, su tüketiminin azaltılması, arsa } \\
\text { kullanım miktarı, her depo için sarf edilen enerjinin miktarı }\end{array}$ \\
\hline $\begin{array}{l}\text { Atıklar ve Geri } \\
\text { Dönüşüm }\end{array}$ & $\begin{array}{l}\text { Atıkların azaltılması } \\
\text { Malzeme ve ürünlerin geri dönüşümü } \\
\text { Bio-enerji malzeme kullanımı }\end{array}$ & $\begin{array}{l}\text { Geri dönüştürülebilir ambalaj oranı, malzeme kayıplarının } \\
\text { azalması, taşıma hasarlarının azalması, sızıntıların azaltılması, } \\
\text { zamanı geçmiş veya eskimiş ürünlerin azalması }\end{array}$ \\
\hline
\end{tabular}

Kaynak: Çetinkaya vd., 2011:62.

\subsubsection{Sosyal Boyutlar}

Sosyal boyutu ile sürdürülebilirlik, gelişmeyi ve kalkınmayı da içeren ilerleme ile toplumun din, hukuk sistemi, eğitim, gelenekler, iletişim gibi ekonomi ile ilişkisi olmayan bir temel üzerinde vücut bulan değerler sistemi ve sosyal normları arasındaki dengeye odaklanır (Akgül, 2010:157).

Bir tedarik zincirinin sosyal sorumluluğunun üç ana yönü vardır: toplum, çalışanlar ve müşteriler (Gopalakrishnan vd., 2012:196). Tedarik zinciri içerisinde yer alan işletmelerin sosyal sorumluluğu, iş dünyasında etik davranışlarda bulunma, ekonomik kalkınmaya katkıda bulunma konusundaki sürekli bağlılık, işgücünün ve ailelerinin yanı sıra yerel topluluk ve toplumun yaşam kalitesini de iyileştirmesi olarak tanımlanır (Castka ve Balzarova, 2008:276). Tablo 3'de sürdürülebilirliğin sosyal boyutları, faydaları ve ölçüm kriterleri verilmiştir.

Tablo 3. Sosyal Boyutlar, Faydalar ve Ölçüm Örnekleri

\begin{tabular}{|c|c|c|}
\hline Sosyal Boyut & Faydalar ve Sağlanan İyileşmeler & Ölçümler \\
\hline $\begin{array}{l}\text { Sağlık ve } \\
\text { Güvenlik }\end{array}$ & $\begin{array}{c}\text { Salınan tehlikeli gaz ve atık } \\
\text { miktarının azalması } \\
\text { Kazaların azalması } \\
\text { Çalışma şartlarının iyileşmesi }\end{array}$ & $\begin{array}{l}\text { İş sağlığı ve güvenliği konularında eğitim alan çalışan/tedarikçi/taşeron } \\
\text { sayısı, firmada meydana gelen kazaların sayısı, 3. partinin sebep olduğu } \\
\text { kazaların sayısı, kayıplar, tehlikeli kazaların miktarı, salınan kimyasal gaz } \\
\text { oranında düşüş sağlanması, kaza riskinin azaltılması }\end{array}$ \\
\hline Çalışanlar & $\begin{array}{c}\text { İstihdam artışı } \\
\text { Eğitim } \\
\text { İş sağlığı ve güvenliğinin } \\
\text { sağlanması }\end{array}$ & $\begin{array}{l}\text { Üretim miktarı, yaratılan yeni istihdam sayısı, yeni sistem için eğitim alan } \\
\text { çalışan sayısı, eğitim gören çalışanların \%'si, uzun dönemde işgücü } \\
\text { sayısı, personel devamsızlığı }\end{array}$ \\
\hline Gürülttü & $\begin{array}{c}\text { Sesin şiddetinde azalma } \\
\text { Zamanlama ve yerleşim düzeni }\end{array}$ & $\begin{array}{l}\text { Gürülttü miktarının düşürülmesi, depolama operasyonundan kaynaklanan } \\
\text { gürültünün azaltılması, üretim alanında ortaya çıkan faaliyetler }\end{array}$ \\
\hline
\end{tabular}

Kaynak: Çetinkaya vd., 2011:63. 


\subsection{Sürdürülebilir Tedarik Zinciri Yönetimi Kapsamında Yapılan Literatür İncelemesi}

Gopalakrishnan vd. (2012), gerçekleştirdikleri araştırma ile havacıllk ve uzay sanayinde faaliyet gösteren BAE'nin (British Aerospace Systems) sürdürülebilirlik girişimleri ve etkinlikleri genel olarak ele alınmış, sürdürülebilir bir tedarik zinciri için gereken temel unsurların; (ekonomik, çevresel, sosyal boyutlar) birbirine olan bağımlılı̆̆ incelenmiştir. Çalışma sonucunda ortaya konulan çerçevede, tedarik zincirinin çeşitli unsurlarının ilişkisel ortaklığının sağlanması ve sürdürülebilirlik boyutlarının bütüncül bir yaklaşımla ele alınmasıyla ekonomik faydalar elde edilebileceği ortaya konmuştur.

Beske vd. (2014) yaptıkları çalışma ile gıda endüstrisini, sürdürülebilir tedarik zinciri yönetimi ve dinamik yetenekler kriterleri ile incelemişlerdir. Hakemli dergilerde İngilizce olarak yayınlanan, sürdürülebilir gıda tedarik zincirleri hakkındaki yayınları (52 makale), içerik analizi yöntemi ile incelemişlerdir. Şirketlerin STZY uygulamaları ile TZY üzerindeki kontrolünü ve rekabet avantajını korumaya yönelik öneriler sunulmuştur. Çalışma sonunda, literatür taramasına dayanarak sekiz farklı öneri sunulmaktadır. Bunlar;

- Bilgi Değerlendirmesi

- Bilgi Edinme

- Yetenek Geliştirme

- Ortak Arama, Seçimi ve Entegrasyonu

- Tedarik Zinciri Bağlantı Vakfı

- Ürün ve Süreç Geliştirme

- İlişki Yönetimi

- Etkin Kontrol

Carter ve Rogers (2008)'ın yaptıkları araştırmanın amacı, tedarik zinciri yönetimi alanında sürdürülebilirlik kavramını tanıtmak ve tedarik zinciri yönetimi bağlamında çevresel, sosyal ve ekonomik performans arasındaki ilişkileri göstermek için kavramsal bir teori oluşturmak ve geniş kapsamlı bir literatür taraması yapmaktır. Çalı̧̧ma sonucunda ortaya konulan öneriler;

- Stratejik olarak STZY' yi üstlenen firmalar, üçlü alt çizginin, üç bileşeninden (ekonomik, çevresel, sosyal boyutlar) sadece bir veya ikisini takip eden firmalardan daha yüksek ekonomik performans elde etmesi beklenmektedir.

- Sosyal, çevresel kaynakları ve bilgiyi birleştiren tedarik zincirlerinin, taklit edilmesi daha zor olabilir, böylece ekonomik sürdürülebilirlik sağlanabilecektir.

- Azalan doğal kaynaklara daha etkili bir şekilde uyum sağlayan organizasyonlar, artan çeşitlilik ve insan haklarında iyileştirme çağrıları gibi sosyal değişimlerle birlikte, daha ekonomik olarak sürdürülebilir olacaktır.

- Kilit dış kaynaklara bağımlı olan firmalar, dikey koordinasyon yoluyla ekonomik sürdürülebilirliklerini geliştirebilirler.

Wolf (2011) yaptığı çalışma ile sürdürülebilir bir tedarik zinciri yönetimi entegrasyonunun, tutarlı ve test edilebilir bir modelini ortaya koymayı amaçlamıştır. Alman imalat endüstrisinden dört örnek alarak, sürdürülebilirliğin $\mathrm{TZY}^{\prime}$ ye entegrasyonunu mümkün kılan veya engelleyen en önemli faktörler belirlenmeye çalışılmaktadır. Araştırma sonucunda ortaya konulan faktörler;

- Sürdürülebilir tedarik zinciri yönetimi entegrasyonu için paydaş entegrasyonu yeteneği gereklidir.

- Sürdürülebilir tedarik zinciri yönetimi entegrasyonu için bir sürdürülebilirlik stratejisi ve uygun performans önlemleri gereklidir.

- Sürdürülebilir tedarik zinciri yönetimi entegrasyonu için liderlik desteği gereklidir.

- Sürdürülebilir tedarik zinciri yönetimi entegrasyonu için ek insan kaynaklarına yatırım yapılması ve yeteneklerin/becerilerin geliştirilmesi gerekmektedir.

- Her seviyedeki tüm tedarikçilerle, yakın tedarikçi ilişkileri, sürdürülebilir tedarik zinciri yönetimi entegrasyonunu desteklemektedir. 
GÜLTEKIN, Salih ve DESTE, Mustafa - Tedarik Zinciri Yönetiminde Sürdürülebilirlik Uygulamaları ve Malatya İli Örneği

Ageron vd. (2012), tedarik zinciri yönetiminde sürdürülebilirliğin önemini kavramak, teorik bir çerçeve geliştirmek ve daha sonra çerçeveyi araçlarla incelemek amaciyla bir çalışma gerçekleştirmişlerdir. Seçilen Fransız şirketlerinin algı ve uygulamalarını kullanarak deneysel bir çalışma yapılmıştır. Çalışmada elde edilen bulgulara göre;

- Dış faktörler veya baskılar STZY' nin gelişimi üzerinde olumlu etkiye sahiptir.

- Sürdürülebilirlik stratejileri ve eylem planları, sürdürülebilir tedarik zinciri yönetimi üzerinde performans hedeflerine göre daha olumlu sonuçlara sahip olma eğilimindedir.

- Aktif, kolektif ve reaktif karar verme yaklaşımlarının STZY üzerinde proaktif, işbirlikçi ve bireysel yaklaşımlardan daha olumlu etkileri vardır.

- Finansal engeller, STZY üzerinde finansal olmayan engellerden daha fazla etkiye sahiptir.

- Müşteri memnuniyeti, tedarikçi yeniliği, kalite ve kapasite gibi önemli faydaların, sürdürülebilir tedarik zinciri üzerinde; teslim süresi, maliyet, esneklik ve envanter optimizasyonundan daha olumlu etkileri vardir.

- Tedarikçinin üst yönetim vizyonu ve destekleri STZY' de kritik bir başarı faktörüdür.

Harms vd. (2012), çalışmalarında, Alman borsalarında işlem gören büyük ve orta büyüklükteki şirketlerin tedarikçi yönetimi ile ilgili iki STZY stratejik yaklaşımını incelemektedir. Ankete dayalı analiz, büyük Alman hisse senedi şirketlerinin ağırlıklı olarak risk odaklı STZY stratejileri uyguladığını ortaya koymaktadır.

Tchaikovsky (2017), hazırlamış olduğu doktora tezinde, kaynak bağımlılığı teorisine dayanarak, sürdürülebilir tedarik zinciri yönetimi, paydaş baskısı ve kurumsal sürdürülebilirlik performansı arasındaki ilişkiyi incelemektedir. Çalışmanın sonuçları, sürdürülebilir uygulamalar ile finansal performans arasında ve paydaş baskısı ile finansal performans arasında anlamlı ve pozitif bir ilişki olduğunu göstermiştir. Çalışmanın sonuçları, sürdürülebilir tedarik zinciri yönetimi ve paydaş baskısının kurumların kurumsal sürdürülebilirlik performansını artırmak için kullandıkları stratejileri doğrudan etkilediğini de göstermiştir.

Ahi ve Searcy (2013), yeşil tedarik zinciri yönetimi ve sürdürülebilir tedarik zinciri yönetiminin yayınlanmış tanımlarını saptamayı ve analiz etmeyi amaçlamışlarıdır. Yeşil tedarik zinciri yönetimi için toplam 22, sürdürülebilir tedarik zinciri yönetimi için 12 tanım belirlemişlerdir. Analiz, YTZY tanımlarının genellikle STZY için olanlardan daha dar kapsamlı olduğunu ve çevresel, akış ve koordinasyon odaklarının özelliklerine vurgu yaptığını göstermektedir. Bazı STZY tanımları, YTZY tanımlarıyla büyük ölçüde örtüşüyor olsa da, STZY' nin temelde YTZY' nin bir uzantısı olduğu iddia edilmektedir.

Seuring ve Müller (2008), uzmanların görüşleri ile katkıda bulunmalarının istendiği bir Delphi çalışmasının bulgularını sunmaktadır. Bu araştırma projesinde üç farklı uzman grubu seçilmiştir; akademik araştırmacılar, sivil toplum kuruluşlarından uzmanlar ve kurumsal sürdürülebilirlik yöneticileri. Çalışmada, STZY kapsamında dört ana konu tanımlanmıştır. Yapılan anket sonucu, dört ana başlık altında öncelik gösteren konular;

- Sürdürülebilir Tedarik Zinciri Yönetimi İçin Baskllar ve Teșvikler: Bu başlık altında iki baskın neden tespit edilmiştir. Bunlar; sürdürülebilir ürün ve hizmetler için nihai müşteri talebi ve hükümet düzenlemeleridir.

- Sürdürülebilir Tedarik Zinciri Yönetimine Etkilerini Belirleme ve Ölçme : Bu başlık altında, temel olarak sürdürülebilirliğin üç boyutunun (ekonomik, çevresel ve sosyal), tedarik zinciri yönetimini nasıl etkiledikleri değerlendirilmiştir. Ekonomik boyut en önemlisi olarak görülmektedir. Sirasıyla çevresel ve sosyal boyutlar gelmektedir.

- $\quad$ Tedarikçi Yönetimi : Çevresel ve sosyal kriterleri içeren tedarikçi seçimi öncelikli olarak görülmüştür. Onu tedarikçilerin denetlenmesi ve izlenmesi konusu takip etmektedir.

- $\quad$ Tedarik Zinciri Yönetimi (Tedarik Zincirinde Yer Alan Tüm Sirketlerin Sorunları) : Bu başlık altındaki en önemli sonuç, tedarik zinciri üyeleri arasındaki işbirliği ve iletişim olarak ortaya çıkmıştır. Bunu tedarik zinciri boyunca risk yönetimi izlemektedir.

Şişman vd. (2016), tedarik zinciri yönetiminin boyutları kapsamında, kurumsal sürdürülebilirliğin, işletmelerin finansal performansı ile ilişkisini incelemiştir. Bu kapsamda araştırmacılar, Borsa İstanbul' da işlem gören ve Sürdürülebilirlik Endeksinde bulunan 50 işletmenin KSS (Kurumsal Sosyal Sorumluluk) ya da sürdürülebilirlik 
raporlarını incelemiş, 2013 yılında uygulanmış olan sürdürülebilir tedarik zinciri yönetimi uygulamalarının, işletmelerin 2014 yılı finansal performanslarına etkisini test etmişlerdir. Elde ettikleri bulgulara göre, ekonomik tedarik zinciri yönetimi uygulamaları ile varlık ve öz sermaye kârlılığı arasında pozitif yönlü ve anlamlı ilişki tespit edilmiş, çevresel ve sosyal tedarik zinciri yönetimi faaliyetleri ile varlık ve öz sermaye kârlılığı arasında ise anlamlı ilişkinin olmadığı sonucuna ulaşmışlardır.

Zailani vd. (2012), yaptıkları araştırma ile sürdürülebilir tedarik zinciri yönetimi uygulamalarının, çevresel satın alma ve sürdürülebilir paketleme uygulama kapsamını araştırmaktadır. Çalışma ayrıca, bu uygulamaların sürdürülebilir tedarik zinciri performansı konusundaki sonuçlarını da incelemektedir. Malezya'daki 400 üretim firması arasında posta yoluyla bir anket yapılmıştır. Çalışma, çevresel satın almanın üç kategori (ekonomik, sosyal ve operasyonel) üzerinde olumlu bir etkiye sahip olduğunu, sürdürülebilir ambalajlamanın ise çevresel, ekonomik ve sosyal sonuçlar üzerinde olumlu bir etkiye sahip olduğunu göstermiştir. Araştırma sonucunda, STZY uygulamalarının, sürdürülebilir tedarik zinciri performansı üzerinde, özellikle ekonomik ve sosyal açıdan olumlu bir etkiye sahip olduğunu ampirik olarak kanıtladığı ifade edilmiştir.

Wittstruck ve Teuteberg' in (2012), ortaya koydukları çalışmanın amacı, elektrik-elektronik endüstrisinde, sürdürülebilir tedarik zinciri yönetiminin kilit başarı faktörlerini belirlemek ve yönetim uygulamalarının etkilerinin analiz edilmesidir. Başarı faktörleri sistematik bir literatür taraması ile tanımlanmış ve daha sonra açıklayıcı bir modele entegre edilmiştir. Sonuçlar, sürekli bilgi alışverişinin tüm tedarik zinciri ortakları için yararlı olduğunu göstermektedir. Bilgi sağlama ve strateji paylaşımının, ağlar içinde başarılı STZY için belirleyici faktörler olduğunu göstermektedir. Ayrıca, kapalı döngü sistemlerinde modellenen işlemlerin, malzeme ve enerji verimliliğini artırmaya katkıda bulunduğu sonucu elde edilmiştir.

Yapılan çalışmalar kapsamında, yeşil tedarik zinciri yönetimi, lojistik yönetimi gibi konu başlıklarının yanında, özgün bir sürdürülebilir tedarik zinciri yönetimi tanımı yapılarak yeni bir çerçeve oluşturma çabası görülmektedir. Yapılmış çalışmalar kapsamında genel olarak görülmektedir ki sürdürülebilir tedarik zinciri yönetimi uygulamalarını hayata geçiren işletmeler, sürdürülebilirlik faaliyetleri için kısa vadede birtakım maliyetlere katlanmak durumunda kalsalar da orta ve uzun vadede; şirket performansı, müşteriler nezdindeki şirket imajı ve olumsuz çevresel etkilerin azaltılması konularında pozitif geri dönüş almaktadırlar.

\section{TEDARİK ZİNCİRİ YÖNETMINNDE SÜRDÜRÜLEBİLİRLİK UYGULAMALARI VE MALATYA ILLI ÖRNEĞİ}

Makalenin bu kısmında araştırmanın konusu, önemi, amacı, modeli, örneklemi, kısıtları (sınırlılıkları), veri toplama yöntemleri, veri analiz yöntemleri ve güvenilirliği detaylı olarak ele alınarak elde edilen bulgular tartışlacaktır.

\subsection{Araştırmanın Kavramsal Modeli}

Günümüz dünyasında hızla artan rekabet koşulları, üretim ve tüketim miktarının, nüfus artışı ile birlikte katlanarak artması ve bunun sonucunda oluşan iklim değişikliği, arz ve enerji güvenliği gibi sorunları beraberinde getirmekte ve sürdürülebilirlik kavramının önemi giderek artmaktadır. Bu bağlamda, tedarik zincirlerinin sürdürülebilir hale getirilmesi, işletmelerin son yıllarda üzerinde önemle durdukları konuların başında gelmektedir.

Üretim işletmelerinde de giderek artan öneminden hareketle, sürdürülebilir tedarik zinciri yönetimi uygulamaları kapsamında, literatür incelenerek elde edilen bilgiler 1şığında, Malatya Organize Sanayi Bölgelerinde faaliyet gösteren işletmeler merkeze alınarak, anket yönteminin kullanıldığı uygulamalı bir araştırma yapılmıştır.

\subsubsection{Araştırmanın Amacı ve Hipotezleri}

Araştırmanın amacı, son yıllarda önemi hızla artan "sürdürülebilirlik" kavramını, tedarik zinciri yönetimi bağlamında ele alarak literatüre katkı sağlanması ve Malatya ili Organize Sanayi Bölgelerinde faaliyet gösteren işletmelerin sürdürülebilir tedarik zinciri yönetimi konusundaki engel ve algılarının tespit edilmesi, engel ve alg1 düzeylerinin işletmelerin temel bazı özelliklerine göre dağılımında farklılık olup olmadığının açıklanmasıdır. Ayrıca bu çalışma ile işletmelerin sürdürülebilir tedarik zinciri yönetimi algı ve engel düzeylerinin, ekonomik, çevresel ve sosyal sürdürülebilirlik performansları ile olan ilişkisi incelenmiştir. Son olarak araştırma konusu 
GÜLTEKIN, Salih ve DESTE, Mustafa - Tedarik Zinciri Yönetiminde Sürdürülebilirlik Uygulamaları ve Malatya İli Örneği

işletmelerin; ekonomik, çevresel ve sosyal sürdürülebilirlik performansları arasındaki ilişki incelenmiştir. Böylelikle elde edilen verilerin, değerlendirme ve çözüm önerileri için kullanılması hem de Malatya ili Organize Sanayi Bölgelerinde faaliyet gösteren işletmelerin sürdürülebilirlik yaklaşımlarını ortaya koyabilecek bir envanter oluşturulmasına katkı sağlanması amaçlanmıştır. Tüm bu amaçlar 1şığında, literatür incelenerek belirlenen hipotezler Tablo 4' de yer almaktadır:

Tablo 4. Hipotezler

\begin{tabular}{|c|c|}
\hline $\begin{array}{c}\text { H1: STZY Algıları, işletmelerin yapısal özelliklerine göre } \\
\text { farklılık göstermektedir. }\end{array}$ & $\begin{array}{l}\boldsymbol{H} 2_{f} \text { : İşletmelerin hammadde tedarik şekline göre STZY } \\
\text { uygulamaları önündeki engeller farkl1lı göstermektedir. }\end{array}$ \\
\hline $\begin{array}{l}\boldsymbol{H 1}_{\boldsymbol{a}}: \text { İşletmelerin faaliyet gösterdiği sektörlere göre STZY algısı } \\
\text { farklılık göstermektedir. }\end{array}$ & $\begin{array}{l}\boldsymbol{H} \boldsymbol{2}_{\boldsymbol{g}} \text { : İşletmelerin ürettikleri ürünlerin nakliyesinde kullandı̆̆ } \\
\text { yönteme göre STZY uygulamaları önündeki engeller farklılık } \\
\text { göstermektedir. }\end{array}$ \\
\hline $\begin{array}{l}H_{1} \text { : İşletmelerin faaliyet sürelerine göre STZY algısı farklılık } \\
\text { göstermektedir. }\end{array}$ & $\begin{array}{l}\boldsymbol{H} 2_{h} \text { : İsletmelerin ISO } 14001 \text { Çevre Yönetim Sistemi } \\
\text { Sertifikasına sahip olup olmamalarına göre STZY uygulamaları } \\
\text { önündeki engeller farklılık göstermektedir. }\end{array}$ \\
\hline $\begin{array}{l}H_{1} \text { : İşletmelerin çalışan sayısına göre STZY algısı farklılık } \\
\text { göstermektedir. }\end{array}$ & $\begin{array}{l}H_{2}: \text { İşletmelerin ISO } 9001 \text { Kalite Yönetim Sistemi Sertifikasına } \\
\text { sahip olup olmamalarına göre STZY uygulamaları önündeki } \\
\text { engeller farklılık göstermektedir. }\end{array}$ \\
\hline $\begin{array}{l}H 1_{d} \text { : İşletmelerin hedef pazar türlerine göre STZY alg1s1 } \\
\text { farklılı göstermektedir. }\end{array}$ & $\begin{array}{l}\boldsymbol{H}_{\boldsymbol{i}} \text { : İşletmelerin bulundukları sektöre yönelik herhangi bir } \\
\text { sertifikaya sahip olup olmama durumlarına göre STZY } \\
\text { uygulamaları önündeki engeller farklılık göstermektedir. }\end{array}$ \\
\hline $\begin{array}{l}\text { H1 }_{e} \text { : İşletmelerin hammaddeleri tedarik ettikleri pazara göre } \\
\text { STZY algisı farklılık göstermektedir. }\end{array}$ & $\begin{array}{l}\text { H3: Issletmelerin STZY algısı ile sürdürülebilirlik } \\
\text { performansları arasında anlamlı bir ilişsi vardır. }\end{array}$ \\
\hline $\begin{array}{l}\text { H1 }_{f}: \text { : İşletmelerin hammadde tedarik şekline göre STZY algisı } \\
\text { farklılık göstermektedir. }\end{array}$ & $\begin{array}{l}\boldsymbol{H 3}_{\boldsymbol{a}} \text { : İşletmelerin STZY algısı ile ekonomik sürdürülebilirlik } \\
\text { performansları arasında anlamlı bir ilişki vardır. }\end{array}$ \\
\hline $\begin{array}{l}H_{g} \text { : İşletmelerin ürettikleri ürünlerin nakliyesinde kullandığ } \\
\text { yönteme göre STZY algısı farklılık göstermektedir. }\end{array}$ & $\begin{array}{l}\boldsymbol{H 3}_{b} \text { : İşletmelerin STZY algısı ile çevresel sürdürülebilirlik } \\
\text { performansları arasında anlamlı bir ilişki vardır. }\end{array}$ \\
\hline $\begin{array}{l}\boldsymbol{H I}_{h}: \text { İşletmelerin ISO } 14001 \text { Çevre Yönetim Sistemi } \\
\text { Sertifikasına sahip olup olmamalarına göre STZY algısı farklılık } \\
\text { göstermektedir. }\end{array}$ & $\begin{array}{l}\boldsymbol{H 3}_{c} \text { : İşletmelerin STZY algısı ile sosyal sürdürülebilirlik } \\
\text { performansları arasında anlamlı bir ilişki vardır. }\end{array}$ \\
\hline $\begin{array}{l}H_{\boldsymbol{i}} \text { : İşletmelerin ISO } 9001 \text { Kalite Yönetim Sistemi Sertifikasına } \\
\text { sahip olup olmamalarına göre STZY algısı farklılık } \\
\text { göstermektedir. }\end{array}$ & $\begin{array}{c}\text { H4: STZY uygulamaları önündeki engeller ile işletmelerin } \\
\text { sürdürülebilirlik performansları arasında anlamlı bir ilişki } \\
\text { vardır. }\end{array}$ \\
\hline $\begin{array}{l}\boldsymbol{H 1}_{\boldsymbol{i}} \text { : İşletmelerin bulundukları sektöre yönelik herhangi bir } \\
\text { sertifikaya sahip olup olmama durumlarına göre STZY algıS1 } \\
\text { farklılık göstermektedir }\end{array}$ & $\begin{array}{l}H_{a} \text { : STZY uygulamaları önündeki engeller ile işletmelerin } \\
\text { ekonomik sürdürülebilirlik performansları arasında anlamlı biı } \\
\text { ilişki vardır. }\end{array}$ \\
\hline $\begin{array}{l}\text { H2: STZY uygulamaları önündeki engeller, işletmelerin } \\
\text { yapısal özelliklerine göre farklılık göstermektedir. }\end{array}$ & $\begin{array}{l}\boldsymbol{H 4}_{b} \text { : STZY uygulamaları önündeki engeller ile işletmelerin } \\
\text { çevresel sürdürülebilirlik performansları arasında anlamlı biı } \\
\text { ilişki vardır. }\end{array}$ \\
\hline $\begin{array}{l}H 2_{a} \text { : İşletmelerin faaliyet gösterdiği sektörlere göre STZY } \\
\text { uygulamaları önündeki engeller farkl1lık göstermektedir. }\end{array}$ & $\begin{array}{l}\boldsymbol{H 4}_{\boldsymbol{c}} \text { : STZY uygulamaları önündeki engeller ile işletmelerin } \\
\text { sosyal sürdürülebilirlik performansları arasında anlamlı bir ilişki } \\
\text { vardır. }\end{array}$ \\
\hline $\begin{array}{l}H 2_{b} \text { : İşletmelerin faaliyet sürelerine göre STZY uygulamaları } \\
\text { önündeki engeller farklılık göstermektedir. }\end{array}$ & $\begin{array}{l}\text { H5: issletmelerin sürdürülebilirlik uygulamalarının boyutlar } \\
\text { (ekonomik, çevresel, sosyal) arasında anlamlı bir ilişsi vardır. }\end{array}$ \\
\hline $\begin{array}{l}\boldsymbol{H} 2_{c} \text { : İşletmelerin çalışan sayısına göre STZY uygulamaları } \\
\text { önündeki engeller farklılık göstermektedir. }\end{array}$ & $\begin{array}{l}\text { H5 }{ }_{a} \text { : İşletmelerin ekonomik sürdürülebilirliğinin yüksek olmas1, } \\
\text { çevresel ve sosyal sürdürülebilirlik düzeylerini olumlu olarak } \\
\text { etkiler. }\end{array}$ \\
\hline $\begin{array}{l}\boldsymbol{H}_{e} \text { : İşletmelerin hammaddeleri tedarik ettikleri pazara göre } \\
\text { STZY uygulamaları önündeki engeller farkl1lık göstermektedir. }\end{array}$ & $\begin{array}{l}\boldsymbol{H 5}_{\boldsymbol{b}} \text { : İşletmelerin çevresel sürdürülebilirliğinin yüksek olmas } \\
\text { sosyal sürdürülebilirlik düzeyini olumlu olarak etkiler. }\end{array}$ \\
\hline
\end{tabular}

\subsubsection{Araştırmanın Kapsamı ve Kısıtları}

Araştırmanın kapsamı, Malatya 1. ve 2. Organize Sanayi Bölgelerinde faaliyet göstermekte olan üretim işletmeleri olarak belirlenmiştir. 1. ve 2. Organize Sanayi müdürlüklerinden elde edilen bilgiler doğrultusunda, hali hazırda üretime devam eden tüm işletmeler ziyaret edilerek, tam sayım metodu ile veri toplanması hedeflenmiştir. Ancak gerek araştırma konusu ile ilgili yetkililere ulaşılamaması, bir kısım işletmenin faaliyetlerine ara vermiş veya durdurmuş olması ve gerekse Covid-19 salgını ile oluşan yeni durum sebebi ile oluşan kısıtlamalardan dolayı, araştırma evrenini resmiyette mevcut bulunandan daha az işletme oluşturmuştur. Sonuç olarak tüm bu kısıtlar altında 19'u elektronik posta yolu ile olmak üzere toplam 70 işletmeye ulaşılmış ve konuya ilişkin veriler toplanmıştır. 


\subsubsection{Araştırmanın Yöntemi}

Araştırma konusu için gerekli olan nicel ve nitel verilerin elde edilebilmesi için, araştırma evreni içerisinde yer alan işletmelere, 2020 yılı Temmuz ayı içerisinde ziyaretler düzenlenerek ilgili yöneticiler ile yüzyüze görüşmeler yapılarak, konu hakkında özet bilgiler verilmiş, önceden hazırlanmış anket formları doldurularak görüşmeler tamamlanmıştır.

Çalışma ile işletmelerin birtakım yapısal özellikleri ile sürdürülebilir tedarik zinciri yönetimi algıları ve STZY uygulamaları önündeki engelleri arasındaki ilişki incelenmiştir. Araştırmanın devamında, işletmelerin söz konusu alg1 ve engellerinin; ekonomik, çevresel ve sosyal sürdürülebilirlik performansları ile olan ilişkileri incelenmiştir. Son olarak işletmelerin, ekonomik, çevresel ve sosyal sürdürülebilirlik performansları arasındaki ilişkiler analiz edilmiştir.

Araştırmada nicel ve nitel araştırma yönteminden anket tekniği kullanılmıştır. Elde edilmiş olan veriler SPSS 22 paket programı ile analiz edilmiştir. Verilerin analizinde t-testi, Tek Yönlü Varyans (One - Way Anova) analizi ve Korelasyon analizi uygulanmıştır. Çalışmanın amacı ve literatür dikkate alındığında araştırma modeli Şekil 2'de gösterilmiştir.

Şekil 2. Araştırma Modeli

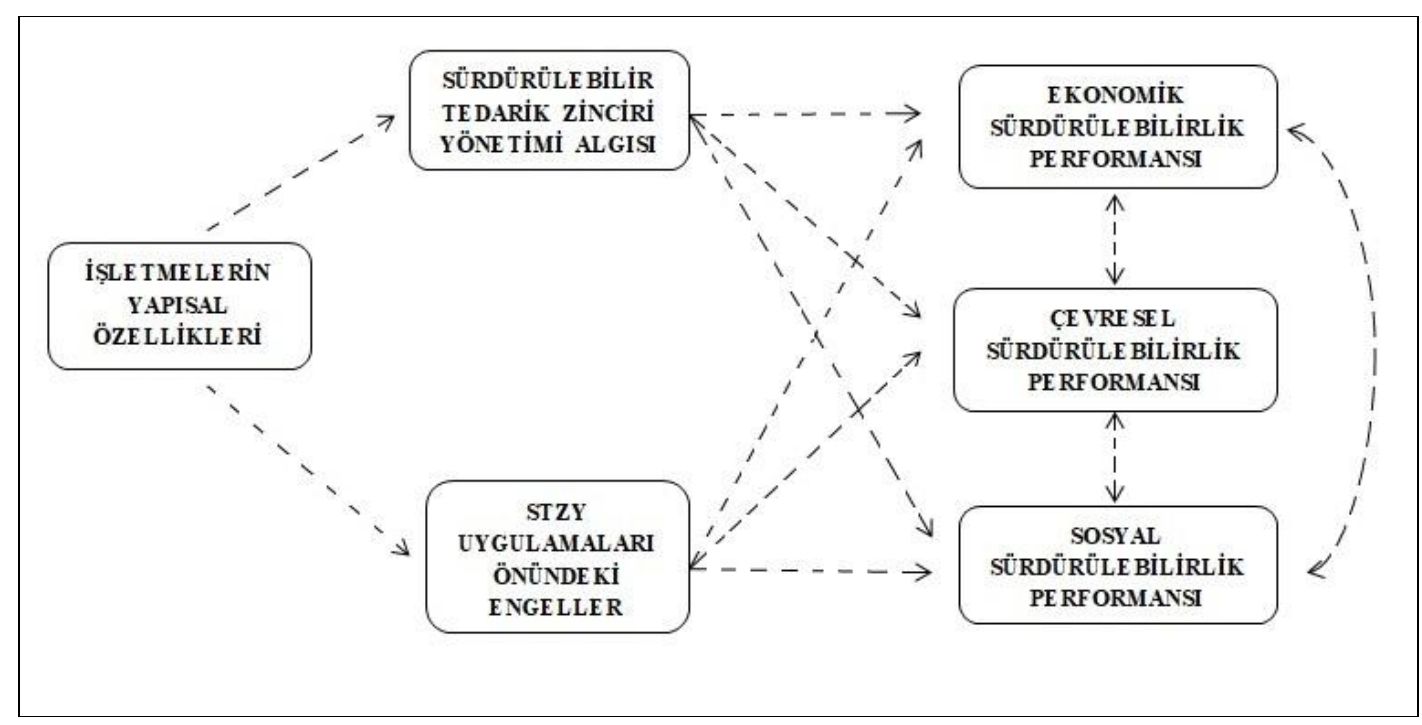

\subsubsection{Veri Toplama Aracının Geliştirilmesi}

Araştırmanın kavramsal modeline uygun olarak geliştirilen anket 6 bölüm ve 36 sorudan oluşmaktadır. İlk bölümde yer alan 10 soru ile işletmelerin birtakım temel özelliklerinin belirlenmesi amaçlanmıştır. 2'inci, 3'üncü ve 4'üncü bölümde sırasıyla işletmelerin ekonomik, çevresel ve sosyal sürdürülebilirlik performanslarının tespitine yönelik sorular yer almaktadır. 5. bölümde işletmelerin sürdürülebilir tedarik zinciri yönetimi algılarının, 6. bölümde ise sürdürülebilir tedarik zinciri yönetimi uygulamaları önündeki engellerin saptanmasına yönelik sorular yer almaktadır.

Çalışma kapsamında öncelikli olarak sürdürülebilir tedarik zinciri yönetimi ve benzeri konularda yapılan çalışmalar incelenmiş ve ulaşılmak istenen amaca uygun anket formu geliştirilmiştir. İşletmelerin ekonomik, çevresel ve sosyal sürdürülebilirlik uygulamalarına yönelik performanslarının tespiti için hazırlanan sorularda, Gedik ve Çil (2015) tarafından kullanılan ölçekten yararlanılmıştır. Araştırmada kullanılan performans ölçeği Tablo.5'de yer almaktadır. Ortaya çıkan performans göstergelerinde, ankete katılım sağlayan işletme yöneticilerinin, anket formuna verdikleri yanıtlar esas alınmıştır. Araştırmaya katılan işletmelerin sürdürülebilir tedarik zinciri yönetimi alg1 ve engellerinin tespiti için hazırlanan sorularda ise Ageron vd. (2012) tarafindan kullanılan ölçeklerden yararlanılmıştır. Araştırma sonucunun tutarlılığı adına ölçekteki sorular 5'li Likert tipi şeklinde sorulmuştur (5:Tamamen Katılıyorum, 4:Katılıyorum, 3:Kararsızım, 2:Katılmıyorum, 1:Hiç Katılmiyorum). 
Tablo 5. Ekonomik, Çevresel ve Sosyal Sürdürülebilirlik Performansı Ölçekleri

\begin{tabular}{|l|l|l|}
\hline \multicolumn{1}{|c|}{$\begin{array}{c}\text { Ekonomik Sürüdürülebilirlik } \\
\text { Uygulamaları }\end{array}$} & \multicolumn{1}{|c|}{$\begin{array}{c}\text { Çevresel Sürdürülüebilirlik } \\
\text { Uygulamaları }\end{array}$} & Sosyal Sürdürülebilirlik Uygulamaları \\
\hline $\begin{array}{l}\text { Isşletmemiz yeterli nakit akışııı her zaman } \\
\text { garanti edebilmektedir. }\end{array}$ & $\begin{array}{l}\text { Ürünlerimizin dayanıklılığının ve } \\
\text { ömrünün artırılmasına yönelik faaliyetler } \\
\text { yürütmekteyiz. }\end{array}$ & $\begin{array}{l}\text { İşletmemiz sosyal kalkınmaya katkıda } \\
\text { bulunmaya çalışmaktadır. }\end{array}$ \\
\hline $\begin{array}{l}\text { Kârlılık ve büyüme hedeflerimize } \\
\text { ulaşmaktayız. }\end{array}$ & $\begin{array}{l}\text { Tehlikeli kimyasal madde kullanımını } \\
\text { azaltmak üzere çalışmalar yapmaktayız. }\end{array}$ & $\begin{array}{l}\text { Çalışanlarımızın yetenek, motivasyon ve } \\
\text { sadakat gibi bireysel yönleri } \\
\text { desteklenmektedir. }\end{array}$ \\
\hline $\begin{array}{l}\text { Üretim süreçlerimizde israfı önleyici } \\
\text { tedbirler alınmaktadır. }\end{array}$ & $\begin{array}{l}\text { Üretim süreçlerimizde ortaya çıkan atık } \\
\text { miktarını azaltıcı önlemler (geri dönüşüm, } \\
\text { verimli atık bertarafı v.s.) almaktayız. }\end{array}$ & $\begin{array}{l}\text { Adil işçilik, insan hakları ve etik ticaret } \\
\text { temel stratejik değerlerimizdendir. }\end{array}$ \\
\hline $\begin{array}{l}\text { Ürünlerimizin kalitesinde süreklilik } \\
\text { sağlamaktayız. }\end{array}$ & $\begin{array}{l}\text { İşletmemizde yenilenebilir enerji } \\
\text { kaynaklarından faydalanılmaktadır. }\end{array}$ & $\begin{array}{l}\text { Çalışanlarımızın ve ailelerinin yaşam } \\
\text { kalitesini artırıcı faaliyetler } \\
\text { yürütülmektedir. }\end{array}$ \\
\hline $\begin{array}{l}\text { Hammadde ve malzeme maliyetlerini } \\
\text { azaltıcı tedbirler almaktayız. }\end{array}$ & $\begin{array}{l}\text { Ürünlerimizin ambalajları geri } \\
\text { dönüştürülebilir niteliktedir. }\end{array}$ & $\begin{array}{l}\text { Tedarikçilerimizin uygun çalışma } \\
\text { koşullarına sahip olmaları adına } \\
\text { faaliyetler yürütülmektedir. }\end{array}$ \\
\hline $\begin{array}{l}\text { Yerel ekonomiyi desteklemek için, satın } \\
\text { almada önceliğimiz yerel tedarikçilerdir. }\end{array}$ & & \\
\hline
\end{tabular}

\subsection{Analiz ve Bulgular}

\subsubsection{Veri Toplama Aracının Güvenirliği}

Araştırmada kullanılan ölçeğin güvenirliğinin test edilmesi amacıyla "Cronbach Alpha" katsayısı kullanılmıştır. Alpha katsayısına bağlı olarak ölçeklerin güvenirliği aşağıdaki gibi ifade edilmektedir:

- $0,00 \leq \alpha<0,40$ ise güvenilir olmayan ölçek.

- $0,40 \leq \alpha<0,60$ ise güvenirliği düşük olan ölçek.

- $0,60 \leq \alpha<0,80$ ise oldukça güvenilir ölçek.

- $\quad 0,800 \leq \alpha<1,00$ ise yüksek derecede güvenilir ölçek.

Aşağıda yer alan Tablo. 6' da uygulamada kullanılan ölçeklerin Cronbach Alpha değerleri ve ölçekler yer almaktadır.

Tablo 6. Ölçek Güvenirliği

\begin{tabular}{|c|c|c|}
\hline Ölçek Adı & Madde Sayısı & Cronbach Alpha Sayısı \\
\hline Genel Ortalama & 26 & $\mathbf{0 , 8 5 4}$ \\
\hline Ekonomik Sürd. Performansı & 6 & $\mathbf{0 , 6 9 4}$ \\
\hline Çevresel Sürd. Performansı & 5 & $\mathbf{0 , 6 2 6}$ \\
\hline Sosyal Sürd. Performansı & 5 & $\mathbf{0 , 7 0 4}$ \\
\hline STZYAlgısı & 5 & $\mathbf{0 , 8 0 5}$ \\
\hline STZY Uygulamaları Önündeki Engeller & 5 & $\mathbf{0 , 8 7 6}$ \\
\hline
\end{tabular}

Tablo. 6'da görüldüğü üzere, ekonomik, çevresel ve sosyal sürdürülebilirlik performansı ölçeklerinin Cronbach Alpha değeri 0,60'ın üzerinde olduğundan, oldukça güvenilir; STZY algısı, STZY uygulamaları önündeki engeller başlıklı ölçeklerin ve genel ölçek ortalamasının Cronbach Alpha değeri 0,80'in üzerinde olduğundan, yüksek derecede güvenilirdir. Yukarıdaki veriler ışığında, ölçeklerin güvenilir olduğu saptanmış ve analizlerde kullanılabileceği kabul edilmiştir. 


\subsubsection{Araştırma Yapılan İşletmelerle İlgili Tanımlayıcı İstatistik Bilgileri}

Araştırma kapsamında ulaşılan 70 işletmeye ait tanımlayıcı istatistik bilgileri aşağıda yer alan Tablo.7 ve Tablo.8'de verilmiştir.

Tablo 7. Araştırma Yapılan İşletmeler İçin Tanımlayııı İstatistikler (1)

\begin{tabular}{|c|c|c|c|c|c|}
\hline \multicolumn{3}{|l|}{ DEĞİŞKEN } & \multicolumn{3}{|l|}{ DEĞİŞKEN } \\
\hline \multicolumn{3}{|c|}{ İşletmelerin Faaliyet Gösterdiği Sektör } & \multicolumn{3}{|l|}{ İşletmelerin Faaliyet Süresi } \\
\hline & Say1 & $\%$ & & Say1 & $\%$ \\
\hline Tekstil & 23 & 32,9 & $1-5$ y1l & 18 & 25,7 \\
\hline Gida & 14 & 20 & $6-10$ yil & 14 & 20 \\
\hline Makine / İmalat & 9 & 12,9 & $11-15$ y1l & 4 & 5,7 \\
\hline Kimya & 3 & 4,3 & $16-20$ y1l & 8 & 11,4 \\
\hline Elektrik / Elektronik & 3 & 4,3 & $21-25$ y1l & 9 & 12,9 \\
\hline Maden & 1 & 1,4 & $26-30$ y1l & 8 & 11,4 \\
\hline Diğer (Cam, Plastik, Otomotiv vs.) & 17 & 24,3 & $31+\mathrm{y} 1 \mathrm{l}$ & 9 & 12,9 \\
\hline TOPLAM & 70 & 100 & TOPLAM & 70 & 100 \\
\hline \multicolumn{3}{|l|}{ DEĞİŞKEN } & \multicolumn{3}{|l|}{ DEĞİŞKEN } \\
\hline \multicolumn{3}{|c|}{ İşletmelerin Çalışan Sayısı } & \multicolumn{3}{|l|}{ İşletmelerin Hedef Pazarı } \\
\hline & Sayı & $\%$ & & Say 1 & $\%$ \\
\hline Mikro İşletme & 3 & 4,3 & Yerel & 3 & 4,3 \\
\hline Küçük İşletme & 32 & 45,7 & Yurt İçi & 11 & 15,7 \\
\hline Orta Büyüklükteki İşletme & 25 & 35,7 & Yurt D1ş1 & 6 & 8,6 \\
\hline \multirow[t]{3}{*}{ Büyük İşletme } & 10 & 14,3 & Yerel + Yurt İçi & 9 & 12,9 \\
\hline & & & Yurt İçi + Yurt D1ş1 & 37 & 52,9 \\
\hline & & & Yerel + Yurt İçi + Yurt Dış1 & 4 & 5,7 \\
\hline TOPLAM & 70 & 100 & TOPLAM & 70 & 100 \\
\hline \multicolumn{3}{|l|}{ DEĞİŞKEN } & \multicolumn{3}{|l|}{ DEĞİŞKEN } \\
\hline \multicolumn{3}{|c|}{ İşletmelerin Hammaddeleri Tedarik Ettiği Pazar } & \multicolumn{3}{|c|}{ İşletmelerin Hammaddeleri Tedarik Şekli } \\
\hline & Say1 & $\%$ & & Say1 & $\%$ \\
\hline Yerel & 8 & 11,4 & İşletmeye Ait Araçlarla & 10 & 14,3 \\
\hline Yurt İçi & 20 & 28,6 & Nakliye Firmalarıyla & 37 & 52,9 \\
\hline Yerel + Yurt İçi & 6 & 8,6 & Tedarikçi Araçlarıyla & 7 & 10 \\
\hline Yurt İçi + Yurt D1ş1 & 35 & 50 & İşletmeye Ait Araçlar+ Nakliye Firmaları & 9 & 12,9 \\
\hline \multirow[t]{3}{*}{ Yerel + Yurt İçi + Yurt Dişı } & 1 & 1,4 & İşletmeye Ait Araçlar + Tedarikçi Araçları & 1 & 1,4 \\
\hline & & & Nakliye Firmaları + Tedarikçi Araçları & 3 & 4,3 \\
\hline & & & İşletmeye Ait Ar.+ Nakliye Fr.+ Tedarikçi Ar. & 3 & 4,3 \\
\hline TOPLAM & 70 & 100 & TOPLAM & 70 & 100 \\
\hline
\end{tabular}


GÜLTEKIN, Salih ve DESTE, Mustafa - Tedarik Zinciri Yönetiminde Sürdürülebilirlik Uygulamaları ve Malatya İli Örneği

Araştırma kapsamında ulaşılan 70 işletmeye ait tanımlayıcı istatistik bilgileri aşağıda yer alan Tablo.8'de verilmiştir;

Tablo 8. Araştırma Yapılan İşletmeler İçin Tanımlayıcı İstatistikler (2)

\begin{tabular}{|c|c|c|c|c|c|}
\hline \multicolumn{3}{|l|}{ DEĞİŞKEN } & \multicolumn{3}{|c|}{ DEĞİŞKEN } \\
\hline \multicolumn{3}{|c|}{ İşletmelerin Ürettikleri Ürünlerin Nakliye Şekli } & \multicolumn{3}{|c|}{ ISO 14001 Çevre Yönetim Sistemi Sertifikası } \\
\hline & Sayı & $\%$ & & Say1 & $\%$ \\
\hline İşletmeye Ait Araçlarla & 8 & 11,4 & Evet & 33 & 47,1 \\
\hline Nakliye Firmalarıyla & 31 & 44,3 & Hayır & 37 & 52,9 \\
\hline İşletmeye Ait Araçlar + Nakliye Firmaları & 31 & 44,3 & & & \\
\hline TOPLAM & 70 & 100 & TOPLAM & 70 & 100 \\
\hline \multicolumn{3}{|l|}{ DEĞİŞKEN } & \multicolumn{3}{|c|}{ DEĞİŞKEN } \\
\hline \multicolumn{3}{|c|}{ İşletmelerin Bulunduğu Sektöre Yönelik Sertifikası } & \multicolumn{3}{|c|}{ ISO 9001 Kalite Yönetim Sistemi Sertifikası } \\
\hline & Say1 & $\%$ & & Say1 & $\%$ \\
\hline Evet & 61 & 87,1 & Evet & 53 & 75,7 \\
\hline Hayır & 9 & 12,9 & Hayır & 17 & 24,3 \\
\hline TOPLAM & 70 & 100 & TOPLAM & 70 & 100 \\
\hline
\end{tabular}

\subsection{2. İşletmelerin Yapısal Özelliklerinin STZY Algısına Etkisinin Analizi}

Çalışmanın bu kısmında araştırma konusu işletmelerin, STZY algılarının, işletmelerin bazı temel özelliklerine göre dağılımı incelenmiştir. İşletmelerin algı düzeyleri için 1 ile 5 arasında bir ölçek kullanılmıştır. Ölçekte, "1" hiç katılmıyorum, "5" tamamen katılıyorum şeklinde ifade edilmiştir. İşletmelerin yapısal özellikleri ise;

- Faaliyet gösterilen sektör,

- Faaliyet süresi,

- Çalışan sayısı,

- İşletmelerin hedef pazarı,

- İşletmelerin hammadde tedarik ettikleri pazar,

- İşletmelerin hammadde tedarik şekli,

- İşletmelerin ürettikleri ürünleri nakliye şekli,

- ISO 14001 Çevre Yönetim Sistemi Sertifikasına sahip olup olmaması,

- ISO 9001 Çevre Yönetim Sistemi Sertifikasına sahip olup olmamas1,

- İşletmelerin bulundukları sektöre yönelik sertifikaya sahip olup olmaması dikkate alınmıştır.

Araştırmada kullanılan ölçekte, işletmelerin STZY algı düzeylerinin ölçülmesi için;

- STZY uygulamaları ürün kalitesini artırır,

- STZY uygulamaları müşteri memnuniyetini artırır,

- STZY faaliyetleri tedarik risklerinin minimize edilmesini sağlar,

- STZY ile işletmeler uzun vadede ekonomik performanslarını iyileştirir,

- STZY ile stokların azaltılması sağlanarak, optimal stok miktarına ulaşılır ifadeleri yer almaktadır.

$\mathrm{Bu}$ kapsamda oluşturulan $\mathbf{H}_{\mathbf{1}}$ hipotezi; "STZY alglları, işletmelerin yapısal özelliklerine göre farklılık göstermektedir", şeklinde ifade edilmiştir. Hipotezi test etmek için, Tek Yönlü Varyans (One - Way Anova) analizi ve t-testi analizi yapılmıştır. Analiz sonuçları Tablo.9 ve Tablo.10’ da yer almaktadır. 
Tablo 9. STZY Algısının İşletmelerin Yapısal Özelliklerine Göre Dağı̆lımına İlişkin Tek Yönlü Varyans Analizi Sonuçları

\begin{tabular}{|c|c|c|c|c|c|}
\hline & Sektör & $\mathbf{n}$ & Ortalama & $\mathbf{F}$ & Anlamlılık (p) \\
\hline \multirow{9}{*}{ STZY ALGISI } & Tekstil & 23 & 4,49 & \multirow{7}{*}{0,848} & \multirow{7}{*}{0,538} \\
\hline & Gida & 14 & 4,6 & & \\
\hline & Makine/ İmalat & 9 & 4,55 & & \\
\hline & Kimya & 3 & 5 & & \\
\hline & Elektrik/Elektronik & 3 & 4,33 & & \\
\hline & Maden & 1 & 4,8 & & \\
\hline & Diğer & 17 & 4,61 & & \\
\hline & Toplam & 70 & & & \\
\hline & Faaliyet Süresi & $\mathbf{n}$ & Ortalama & $\mathbf{F}$ & Anlamlılık (p) \\
\hline \multirow{9}{*}{ STZY ALGISI } & $1-5$ y1l & 18 & 4,62 & \multirow{7}{*}{0,185} & \multirow{7}{*}{0,98} \\
\hline & $6-10$ y1l & 14 & 4,6 & & \\
\hline & $11-15$ y1l & 4 & 4,6 & & \\
\hline & $16-20$ y1l & 8 & 4,57 & & \\
\hline & $21-25$ y1l & 9 & 4,44 & & \\
\hline & $26-30$ y1l & 8 & 4,57 & & \\
\hline & $31+\mathrm{y} 11$ & 9 & 4,53 & & \\
\hline & Toplam & 70 & & & \\
\hline & Çalışan Sayısı & $\mathbf{n}$ & Ortalama & $\mathbf{F}$ & Anlamlılık (p) \\
\hline \multirow{6}{*}{ STZY ALGISI } & Mikro İşletme & 3 & 4,26 & \multirow{4}{*}{0,985} & \multirow{4}{*}{0,40} \\
\hline & Küçük İşletme & 32 & 4,63 & & \\
\hline & Orta Büyüklükteki İşletme & 25 & 4,56 & & \\
\hline & Büyük İşletme & 10 & 4,46 & & \\
\hline & Toplam & 70 & & & \\
\hline & Hedef Pazar & $\mathbf{n}$ & Ortalama & $\mathbf{F}$ & Anlamlılık (p) \\
\hline \multirow{7}{*}{ STZY ALGISI } & Yerel & 3 & 4,46 & \multirow{6}{*}{0,284} & \multirow{6}{*}{0,92} \\
\hline & Yurt İçi & 11 & 4,45 & & \\
\hline & Yurt D1ş1 & 6 & 4,53 & & \\
\hline & Yerel + Yurt İçi & 9 & 4,6 & & \\
\hline & Yurt İçi + Yurt Diş1 & 37 & 4,61 & & \\
\hline & Yerel + Yurt İçi + Yurt Diş1 & 4 & 4,55 & & \\
\hline & Toplam & 70 & & & \\
\hline
\end{tabular}

"Işsletmelerin hedef pazar türüne göre STZY algısı farklılık göstermektedir", yaklaşımına ilişkin yapılan test sonucunda; $\mathrm{p}=0,920>\alpha=0,05$ bulunmuştur. $\mathrm{Bu}$ sonuca göre işletmelerin hedef pazarlarında görülen değişikliğin STZY algıları üzerinde anlamlı bir farklılık göstermediği kabul edilecektir. 
Tablo 10. STZY Algısının İşletmelerin Yapısal Özelliklerine Göre Dağılımına İlişkin Tek Yönlü Varyans Analizi Sonuçları (2)

\begin{tabular}{|c|c|c|c|c|c|}
\hline & Hammadde Tedarik Edilen Pazar & $\mathbf{n}$ & Ortalama & $\mathbf{F}$ & Anlamlılık (p) \\
\hline \multirow{7}{*}{ STZY ALGISI } & Yerel & 8 & 4,65 & \multirow{5}{*}{0,505} & \multirow{5}{*}{0,732} \\
\hline & Yurt İçi & 20 & 4,57 & & \\
\hline & Yerel + Yurt İçi & 6 & 4,6 & & \\
\hline & Yurt İçi + Yurt Diş1 & 35 & 4,56 & & \\
\hline & Yerel + Yurt İçi + Yurt Dış1 & 1 & 4 & & \\
\hline & Toplam & 70 & & & \\
\hline & Hammadde Tedarik Şekli & $\mathbf{n}$ & Ortalama & $\mathbf{F}$ & Anlamlılık (p) \\
\hline \multirow{9}{*}{ STZY ALGISI } & İşletmeye Ait Araçlar & 10 & 4,7 & \multirow{7}{*}{1,568} & \multirow{7}{*}{0,171} \\
\hline & Nakliye Firmaları & 37 & 4,58 & & \\
\hline & Tedarikçi Araçları & 7 & 4,48 & & \\
\hline & İşletmeye Ait Araçlar + Nakliye Firmaları & 9 & 4,26 & & \\
\hline & İşletmeye Ait Araçlar + Tedarikçi Araçları & 1 & 5 & & \\
\hline & Nakliye Firmaları + Tedarikçi Araçları & 3 & 4,93 & & \\
\hline & İşletmeye Ait Ar.+ Nakliye Fr.+ Tedarikçi Ar. & 3 & 4,53 & & \\
\hline & Toplam & 70 & & & \\
\hline & Ürünlerin Nakliye Şekli & $\mathbf{n}$ & Ortalama & $\mathbf{F}$ & Anlamlılık (p) \\
\hline \multirow{4}{*}{ STZY ALGISI } & İşletmeye Ait Araçlar & 8 & 4,55 & \multirow{3}{*}{0,859} & \multirow{3}{*}{0,428} \\
\hline & Nakliye Firmaları & 31 & 4,5 & & \\
\hline & İşletmeye Ait Araçlar + Nakliye Firmaları & 31 & 4,64 & & \\
\hline & Toplam & 70 & & & \\
\hline
\end{tabular}

"Işsletmelerin hammaddeleri tedarik ettikleri pazara göre STZY algisı farklılık göstermektedir", yaklaşımına ilişskin yapılan test sonucunda; $p=0,732>\alpha=0,05$ bulunmuştur. Bu sonuca göre işletmelerin hammaddelerini tedarik ettikleri pazardaki 83 değişikliklerin, STZY algıları üzerinde anlamlı bir farklılık göstermediği kabul edilmektedir.

İşletmelerin STZY algılarının, ISO 14001 Çevre Yönetim Sistemi, ISO 9001 Kalite Yönetim Sistemi Sertifikası ve faaliyet gösterdikleri sektöre yönelik herhangi bir sertifikaya sahip olup olmama durumlarına göre dağılımına ilişkin olarak uygulanan t-testi sonuçları Tablo.11'de gösterilmiştir.

Tablo 11. İşletmelerin STZY Algılarının Araştırma Konusu Sertifikalara Sahip Olup Olmama Durumlarına Göre Dağılımına İlişkin T- Testi Sonuçları

\begin{tabular}{|c|c|c|c|c|c|c|c|}
\hline & Sertifika Bulunma Durumu & & & & A lom & CS & Ortalo \\
\hline \multirow{3}{*}{ STZY Algisı } & ISO 14001 Sertifikası Bulunma Durumu & & & & & & \\
\hline & Evet & 33 & 4,581 & \multirow{2}{*}{0,19} & \multirow{2}{*}{0,85} & 0,472 & \multirow{2}{*}{0,019} \\
\hline & Hayır & 37 & 4,562 & & & 0,391 & \\
\hline \multirow{3}{*}{ STZY Algisı } & ISO 9001 Sertifikası Bulunma Durumu & $\mathbf{n}$ & Ortalama & $\mathbf{t}$ & Anlamlılık (p) & SS & Ortalama Farkı \\
\hline & Evet & - & - & \multirow{2}{*}{ - } & \multirow{2}{*}{-} & - & \multirow{2}{*}{-} \\
\hline & Hayır & 17 & 4,752 & & & 0,287 & \\
\hline \multirow{3}{*}{ STZY Algisı } & Sektöre Yönelik Sertifika Bulunma Durumu & $\mathbf{n}$ & Ortalama & $\mathbf{t}$ & Anlamlılık (p) & SS & Ortalama Farkı \\
\hline & Evet & - & - & \multirow{2}{*}{-} & & - & \multirow{2}{*}{ - } \\
\hline & Hayır & 9 & 4,644 & & & 0,384 & \\
\hline
\end{tabular}


H1: "İsletmelerin ISO 9001 Kalite Yönetim Sistemi Sertifikasına sahip olup olmamalarına göre STZY algısl farklılık göstermektedir", hipotezine ilişkin yapılan test sonucunda anlamlılık değeri; $\mathrm{p}=0,014<\alpha=0,05$ sonucuna ulaşılmıştır. Böylece H1ı hipotezi kabul edilmiştir. Bu sonuca göre işletmelerin ISO 9001 Kalite Yönetim Sistemi Sertifikasına sahip olma durumlarının, işletmelerin STZY algısı üzerinde anlamlı bir farklılık gösterdiği kabul edilecektir. ISO 9001 Kalite Yönetim Sistemi Sertifikasına sahip olmayan işletmeler, 4,75 ortalama ile söz konusu sertifikaya sahip olan işletmelere göre, daha yüksek bir STZY algı düzeyine sahip olduğu kabul edilmiştir.

\subsection{3. İşletmelerin Yapısal Özelliklerinin STZY Uygulamaları Önündeki Engellere Olan Etkisinin Analizi}

Araştırma konusu işletmelerin, sürdürülebilir tedarik zinciri yönetimi uygulamalarına engel olarak gördükleri başlıklar, literatür ve ilgili çalışmalar 1şı̆̆ında hazırlanan 5 maddelik ölçek üzerinden değerlendirilmiştir. İşletmelerin STZY uygulamaları önündeki engelleri;

- Finansal maliyetler,

- STZY' ye yönelik faaliyetlerin yatırım getirilerinin yetersiz bulunması,

- İşletmenin işgücü yeteneklerinin STZY uygulamaları için yetersiz olması,

- Üst yönetimin STZY faaliyetlerine olan desteğinin yetersiz olmas1,

- İşletmenin tesisleri açısından sürdürülebilirlik uygulamaları için yetersiz olması olarak belirlenmiştir.

Bu kapsamda oluşturulan $\mathbf{H}_{2}$ hipotezi; "STZY uygulamaları önündeki engeller, işletmelerin yapısal özelliklerine göre farklılık göstermektedir", şeklinde ifade edilmiştir. İşletmelerin yapısal özelliklerinin, STZY uygulamaları önündeki engellere olan etkilerini ölçmek için oluşturulan hipotezler ışığında, Tek Yönlü Varyans (One - Way Anova) analizi ve t-testi analizi yapılmıştır. Tek Yönlü Varyans Analizi sonuçları Tablo.12 ve Tablo.13'de, ttesti analizi sonuçları ise Tablo.14'de yer almaktadır.

$H_{c}$ : "İ̧̧letmelerin çalışan sayısına göre STZY uygulamaları önündeki engeller farklllk göstermektedir", hipotezine ilişkin yapılan test sonucunda; $p=0,014<\alpha=0,05$ sonucuna ulaşılmıştır. Böylece $\boldsymbol{H 2}_{\boldsymbol{c}}$ hipotezi kabul edilmiştir. Bu sonuca göre işletmelerdeki çalışan sayılarının, STZY uygulamaları önündeki engeller üzerinde anlamlı bir farklılık gösterdiği kabul edilecektir. STZY uygulamaları önündeki engel düzeyi en yüksek olan işletmeler, 3,8 ortalama ile mikro işletmeler olarak kabul edilmiştir. Onları 3,05 ortalama ile ikinci sırada yer alan küçük işletmeler takip etmektedir.

$H_{2}$ : "IŞletmelerin hammaddeleri tedarik ettikleri pazara göre STZY uygulamaları önündeki engeller farklllı göstermektedir", hipotezine ilişkin yapılan test ile $\mathrm{p}=0,038<\alpha=0,05$ sonucuna ulaşı1mıştır. Elde edilen sonuca göre, işletmelerin hammaddeleri tedarik etmiş oldukları pazarlardaki farklılıkların, STZY uygulamaları önündeki engeller üzerinde anlamlı bir değişime neden olduğu kabul edilmektedir. Böylece $\boldsymbol{H} \boldsymbol{2}_{\boldsymbol{e}}$ hipotezi kabul edilecektir. $\mathrm{Bu}$ sonuca göre, hammaddelerini yalnızca yerel pazardan tedarik eden işletmelerin, STZY uygulamaları önündeki engel düzeyi 3,67 ortalama ile ilk sırada yer almaktadır. Onu ikinci sırada, 3,15 ortalamaya sahip olan, hammaddelerini yalnızca yurtiçinden temin eden işletmeler takip etmektedir.

$H_{f}$ : "Işletmelerin hammadde tedarik şekline göre STZY uygulamaları önündeki engeller farklılık göstermektedir", hipotezine ilişkin yapılan test sonucunda; $\mathrm{p}=0,032<\alpha=0,05$ bulunmuştur. Böylece işletmelerin hammadde tedarik şeklinin (işletmeye ait araçlar, nakliye firmaları vs.) STZY uygulamaları önündeki engeller üzerindeki dağılımında anlamlı bir değişim gösterdiği kabul edilecektir. Elde edilen bulgulara göre $\boldsymbol{H} \boldsymbol{2}_{f}$ hipotezi kabul edilmektedir. Üretimde ihtiyaç duyulan hammaddeleri, yalnızca işletmeye ait araçlar ile tedarik eden işletmelerin, STZY uygulamaları önündeki engel düzeyi, 3,74 ortalama ile birinci sırada yer almaktadır. 3,05 ortalama ile yalnızca tedarikçi araçları ile hammadde temini yapan işletmelerin, STZY uygulamaları önündeki engel düzeyinin, ikinci sırada yer aldığı kabul edilmiştir. 
Tablo 12. STZY Uygulamaları Önündeki Engellerin İşletmelerin Yapısal Özelliklerine Göre Dağıllımına İlişsin Tek Yönlü Varyans Analizi Sonuçları

\begin{tabular}{|c|c|c|c|c|c|}
\hline & Sektör & $\mathbf{n}$ & Ortalama & $\mathbf{F}$ & Anlamlılık (p) \\
\hline \multirow{8}{*}{$\begin{array}{c}\text { STZY Uygulamaları Önündeki } \\
\text { Engeller }\end{array}$} & Tekstil & 23 & 2,76 & \multirow{7}{*}{1,043} & \multirow{7}{*}{0,406} \\
\hline & Gida & 14 & 3,21 & & \\
\hline & Makine/ İmalat & 9 & 2,33 & & \\
\hline & Kimya & 3 & 3,2 & & \\
\hline & Elektrik/Elektronik & 3 & 2,86 & & \\
\hline & Maden & 1 & 2,6 & & \\
\hline & Diğer & 17 & 3,18 & & \\
\hline & Toplam & 70 & & & \\
\hline & Faaliyet Süresi & $\mathbf{n}$ & Ortalama & $\mathbf{F}$ & Anlamlılık (p) \\
\hline \multirow{8}{*}{$\begin{array}{c}\text { STZY Uygulamaları Önündeki } \\
\text { Engeller }\end{array}$} & $1-5$ y1l & 18 & 2,76 & \multirow{7}{*}{0,262} & \multirow{7}{*}{0,953} \\
\hline & $6-10$ yil & 14 & 2,95 & & \\
\hline & $11-15$ y1l & 4 & 3,2 & & \\
\hline & $16-20$ y1l & 8 & 3,25 & & \\
\hline & $21-25$ y1l & 9 & 2,82 & & \\
\hline & $26-30$ y1l & 8 & 2,87 & & \\
\hline & $31+\mathrm{y} 1 \mathrm{l}$ & 9 & 2,91 & & \\
\hline & Toplam & 70 & & & \\
\hline & Çalışan Sayısı & $\mathbf{n}$ & Ortalama & $\mathbf{F}$ & Anlamlılık (p) \\
\hline \multirow{5}{*}{$\begin{array}{c}\text { STZY Uygulamaları Önündeki } \\
\text { Engeller }\end{array}$} & Mikro İşletme & 3 & 3,8 & \multirow{4}{*}{3,785} & \multirow{4}{*}{0,014} \\
\hline & Küçük İşletme & 32 & 3,05 & & \\
\hline & Orta Büyüklükteki İşletme & 25 & 2,99 & & \\
\hline & Büyük İşletme & 10 & 2,06 & & \\
\hline & Toplam & 70 & & & \\
\hline & Hedef Pazar & $\mathbf{n}$ & Ortalama & $\mathbf{F}$ & Anlamlılık (p) \\
\hline \multirow{7}{*}{$\begin{array}{c}\text { STZY Uygulamaları Önündeki } \\
\text { Engeller }\end{array}$} & Yerel & 3 & 2,73 & \multirow{6}{*}{0,866} & \multirow{6}{*}{0,509} \\
\hline & Yurt İçi & 11 & 2,87 & & \\
\hline & Yurt Diş1 & 6 & 3,36 & & \\
\hline & Yerel + Yurt İçi & 9 & 2,64 & & \\
\hline & Yurt İçi + Yurt D1ş1 & 37 & 3,02 & & \\
\hline & Yerel + Yurt İçi + Yurt Diş1 & 4 & 2,2 & & \\
\hline & Toplam & 70 & & & \\
\hline
\end{tabular}

STZY uygulamaları önündeki engellerin işletmelerin yapısal özelliklerine göre dağılımına ilişkin tek yönlü varyans analizi sonuçlarının ikinci kısmı Tablo.13'de verilmiştir. 
Tablo 13. STZY Uygulamaları Önündeki Engellerin İşletmelerin Yapısal Özelliklerine Göre Dağılımına İlişkin Tek Yönlü Varyans Analizi Sonuçları (2)

\begin{tabular}{|c|c|c|c|c|c|}
\hline & Hammadde Tedarik Edilen Pazar & $\mathbf{n}$ & Ortalama & $\mathbf{F}$ & Anlamlılık (p) \\
\hline \multirow{7}{*}{$\begin{array}{l}\text { STZY Uygulamaları } \\
\text { Önündeki Engeller }\end{array}$} & Yerel & 8 & 3,67 & \multirow{5}{*}{2,697} & \multirow{5}{*}{0,038} \\
\hline & Yurt İçi & 20 & 3,15 & & \\
\hline & Yerel + Yurt İçi & 6 & 2,23 & & \\
\hline & Yurt İçi + Yurt Dış1 & 35 & 2,76 & & \\
\hline & Yerel + Yurt İçi + Yurt Dış1 & 1 & 2 & & \\
\hline & Toplam & 70 & & & \\
\hline & Hammadde Tedarik Şekli & $\mathbf{n}$ & Ortalama & $\mathbf{F}$ & Anlamlılık (p) \\
\hline \multirow{9}{*}{$\begin{array}{l}\text { STZY Uygulamaları } \\
\text { Önündeki Engeller }\end{array}$} & İşletmeye Ait Araçlar & 10 & 3,74 & \multirow{7}{*}{2,491} & \multirow{7}{*}{0,032} \\
\hline & Nakliye Firmaları & 37 & 2,91 & & \\
\hline & Tedarikçi Araçları & 7 & 3,05 & & \\
\hline & İşletmeye Ait Araçlar + Nakliye Firmaları & 9 & 2,48 & & \\
\hline & İşletmeye Ait Araçlar + Tedarikçi Araçları & 1 & 1 & & \\
\hline & Nakliye Firmaları + Tedarikçi Araçları & 3 & 2,46 & & \\
\hline & İşletmeye Ait Ar. + Nakliye Fr.+ Tedarikçi Ar. & 3 & 2,4 & & \\
\hline & Toplam & 70 & & & \\
\hline & Ürünlerin Nakliye Şekli & $\mathbf{n}$ & Ortalama & $\mathbf{F}$ & Anlamlılık (p) \\
\hline \multirow{4}{*}{$\begin{array}{l}\text { STZY Uygulamaları } \\
\text { Önündeki Engeller }\end{array}$} & İşletmeye Ait Araçlar & 8 & 2,87 & \multirow{3}{*}{0,286} & \multirow{3}{*}{0,752} \\
\hline & Nakliye Firmaları & 31 & 3,02 & & \\
\hline & İşletmeye Ait Araçlar + Nakliye Firmaları & 31 & 2,83 & & \\
\hline & Toplam & 70 & & & \\
\hline
\end{tabular}

H2 ${ }_{h}$ : "Işsletmelerin ISO 14001 Çevre Yönetim Sistemi Sertifikasına sahip olup olmamalarına göre STZY uygulamaları önündeki engeller farklılık göstermektedir", hipotezine ilişkin yapılan test sonucunda anlamlılık değeri; $\mathrm{p}=0,99>\alpha=0,05$ bulunmuştur. Elde edilen sonuca göre $\boldsymbol{H} \boldsymbol{2}_{\boldsymbol{h}}$ hipotezi reddedilmiştir. Böylelikle işletmelerin ISO 14001 Çevre Yönetim Sistemi Sertifikasına sahip olma durumlarının, STZY uygulamaları önündeki engeller üzerindeki dağılımında anlamlı bir farklılık göstermediği kabul edilmektedir.

H2: "ISsletmelerin ISO 9001 Kalite Yönetim Sistemi Sertifikasına sahip olup olmamalarına göre STZY uygulamaları önündeki engeller farklıllk göstermektedir", hipotezine ilişkin yapılan test sonucunda; $\mathrm{p}=0,566>$

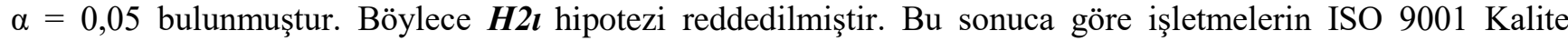
Yönetim Sistemi Sertifikasına sahip olma durumlarının, işletmelerin STZY uygulamaları önündeki engeller üzerinde anlamlı bir farklılık göstermediği kabul edilecektir.

Tablo 14. İşletmelerin STZY Uygulamaları Önündeki Engellerinin Araştırma Konusu Sertifikalara Sahip Olup Olmama Durumlarına Göre Dağılımına İlişkin T- Testi Sonuçları

\begin{tabular}{|c|c|c|c|c|c|c|c|}
\hline \multirow{4}{*}{$\begin{array}{c}\text { STZY } \\
\text { Uygulamaları } \\
\text { Önündeki } \\
\text { Engeller }\end{array}$} & Sertifika Bulunma Durumu & \multirow{2}{*}{$\mathbf{n}$} & \multirow{2}{*}{ Ortalama } & \multirow{2}{*}{$\mathbf{t}$} & \multirow{2}{*}{ Anlamlılık (p) } & \multirow{2}{*}{ SS } & \multirow{2}{*}{ Ortalama Fark } \\
\hline & ISO 14001 Sertifikası Bulunma Durumu & & & & & & \\
\hline & Evet & 33 & 2,921 & \multirow{2}{*}{$-0,013$} & \multirow{2}{*}{0,99} & 1,103 & \multirow{2}{*}{$-0,003$} \\
\hline & Hayır & 37 & 2,924 & & & 0,945 & \\
\hline \multirow{3}{*}{$\begin{array}{c}\text { STZY } \\
\text { Uygulamaları } \\
\text { Önündeki } \\
\text { Engeller }\end{array}$} & ISO 9001 Sertifikası Bulunma Durumu & & & & & & \\
\hline & Evet & 53 & 2,883 & \multirow{2}{*}{$-0,577$} & \multirow{2}{*}{0,566} & 1,03 & \multirow{2}{*}{$-0,164$} \\
\hline & Hayır & 17 & 3,047 & & & 0,981 & \\
\hline \multirow{3}{*}{$\begin{array}{c}\text { STZY } \\
\text { Uygulamaları } \\
\text { Önündeki } \\
\text { Engeller }\end{array}$} & Sektöre Yönelik Sertifika Bulunma Durumu & & & & & & \\
\hline & Evet & 61 & 2,924 & \multirow{2}{*}{0,037} & \multirow{2}{*}{0,971} & 1,008 & \multirow{2}{*}{0,013} \\
\hline & Hayır & 9 & 2,911 & & & 1,122 & \\
\hline
\end{tabular}

H2: "İsletmelerin bulundukları sektöre yönelik herhangi bir sertifikaya sahip olup olmama durumlarına göre STZY uygulamaları önündeki engeller farklılık göstermektedir", hipotezine ilişkin yapılan test sonucunda; $\mathrm{p}=0,971>\alpha=0,05$ bulunmuştur. Bu sonuca göre işletmelerin faaliyet göstermiş oldukları sektöre yönelik 
GÜLTEKIN, Salih ve DESTE, Mustafa - Tedarik Zinciri Yönetiminde Sürdürülebilirlik Uygulamaları ve Malatya İli Örneği

herhangi bir sertifikaya sahip olup olmama durumlarının, STZY uygulamaları önündeki engeller üzerinde anlamlı bir farklılığa neden olmadığı kabul edilecek, $\boldsymbol{H}_{\boldsymbol{i}}$ hipotezi reddedilecektir.

\subsection{4. İşletmelerin STZY Algısı, STZY Önündeki Engelleri ve Sürdürülebilirlik Performansları Arasındaki İlişkilerin İncelenmesi}

Araştırmanın bu bölümünde, oluşturulan araştırma modelini ve hipotezleri test etmeye yönelik yapılmış olan Korelasyon analizinin sonuçları yer almaktadır. Burada işletmelerin STZY algısı ve STZY önündeki engellerin, boyutlarıyla, sürdürülebilirlik performansına etkisi incelenmiştir. Son olarak da sürdürülebilirlik performansları (ekonomik, sosyal, çevresel) arasındaki ilişki analiz edilmiştir. Bu kapsamda oluşturulan hipotezler;

- H3: İşletmelerin STZY algısı ile sürdürülebilirlik performansları arasında anlamlı bir ilişki vardır.

- H4: STZY önündeki engeller ile işletmelerin sürdürülebilirlik performansları arasında anlamlı bir ilişki vardir.

- H5: İşletmelerin sürdürülebilirlik uygulamalarının boyutları (ekonomik, çevresel, sosyal) arasında anlamlı bir ilişki vardır şeklidedir.

Korelasyon analizinde 5 değişken arasındaki ilişki incelenmiştir. Analiz sonuçları Tablo.15'de yer almaktadır.

$\boldsymbol{H 3}_{a}$ : "İŞletmelerin STZY algısı ile ekonomik sürdürülebilirlik performansları arasında anlamlı bir ilişki vardır", hipotezine ilişkin yapılan test sonucunda; $\mathrm{r}=0,399$ bulunmuştur $(\mathrm{p}<0,001)$. Böylece $\boldsymbol{H 3}_{\boldsymbol{a}}$ hipotezi kabul edilmektedir. Ayrıca işletmelerin STZY algıları ile ekonomik sürdürülebilirlik performansları arasında pozitif ilişki vardır.

$\boldsymbol{H}_{b}$ : "İ̧letmelerin STZY algısı ile çevresel sürdürülebilirlik performansları arasında anlamlı bir ilişki vardır", hipotezine ilişkin yapılan test sonucunda; $r=0,390$ bulunmuştur $(\mathrm{p}<0,001)$. Böylelikle $\boldsymbol{H 3}_{\boldsymbol{b}}$ hipotezi kabul edilecektir. Araştırmaya katılan işletmelerin STZY algıları ile çevresel sürdürülebilirlik performansları arasındaki ilişkinin yönü pozitiftir.

Tablo 15. Korelasyon Tablosu

\begin{tabular}{|c|c|c|c|c|c|}
\hline & $\begin{array}{c}\text { Ekonomik } \\
\text { Sürd. }\end{array}$ & $\begin{array}{c}\text { Çevresel } \\
\text { Sürd. }\end{array}$ & Sosyal Sürd. & $\begin{array}{c}\text { STZY } \\
\text { Alg1s1 }\end{array}$ & $\begin{array}{c}\text { STZY Uygulamalar1 } \\
\text { Önündeki Engeller }\end{array}$ \\
\hline Ekonomik Sürdürülebilirlik & 1 & $0,514^{* *}$ & $0,615^{* *}$ & $0,399^{* *}$ & 0,186 \\
\hline Çevresel Sürdürülebilirlik & & 1 & $0,505^{* *}$ & $0,390^{* *}$ & 0,228 \\
\hline Sosyal Sürdürülebilirlik & & & 1 & $0,464^{* *}$ & 0,116 \\
\hline STZY Algıs1 & & & & 1 & 0,117 \\
\hline STZY Uygulamaları Önündeki Engeller & & & & & 1 \\
\hline
\end{tabular}

$H_{3}$ : "İ̧sletmelerin STZY algısı ile sosyal sürdürülebilirlik performansları arasında anlamlı bir ilişki vardır", hipotezine ilişkin yapılan test sonucunda; $r=0,464$ bulunmuştur $(\mathrm{p}<0,001)$. Elde edilen analiz sonucu $\boldsymbol{H 3}_{\boldsymbol{c}}$ hipotezi kabul edilmektedir. Test sonucu, işletmelerin STZY algıları ile sosyal sürdürülebilirlik performansları arasında pozitif ilişkinin varlığı saptanmıştır.

$\boldsymbol{H 4}_{a}$ : "STZY önündeki engeller ile işletmelerin ekonomik sürdürülebilirlik performansları arasında anlamlı bir ilişki vardır", hipotezine ilişkin yapılan test sonucunda; $r=0,186$ bulunmuştur $(\mathrm{p}<0,001)$. Elde edilen bulgulara göre, STZY önündeki engeller ile işletmelerin ekonomik sürdürülebilirlik performansları arasında çok zayıf bir ilişki vardır. Böylece $\boldsymbol{H} \boldsymbol{4}_{\boldsymbol{a}}$ hipotezi reddedilecektir.

$\boldsymbol{H 4}_{b}$ : "STZY önündeki engeller ile işletmelerin çevresel sürdürülebilirlik performansları arasında anlamlı bir iliş̧ki vardır", hipotezine ilişkin yapılan test sonucunda; $r=0,228$ bulunmuştur ( $<<0,001)$. Bu sonuca göre, STZY önündeki engeller ile işletmelerin çevresel sürdürülebilirlik performansları arasında çok zayıf bir ilişki olduğundan $\boldsymbol{H}_{b}$ hipotezi reddedilmektedir.

H4 : "STZY önündeki engeller ile işletmelerin sosyal sürdürülebilirlik performansları arasında anlamlı bir ilişki vardır", hipotezine ilişkin yapılan test sonucunda; $\mathrm{r}=0,116$ bulunmuştur $(\mathrm{p}<0,001)$. Elde edilen sonuca göre, STZY önündeki engeller ile işletmelerin sosyal sürdürülebilirlik performansları arasında çok zayıf bir ilişki vardır. Böylece $\boldsymbol{H} \boldsymbol{4}_{c}$ hipotezi reddedilecektir. 


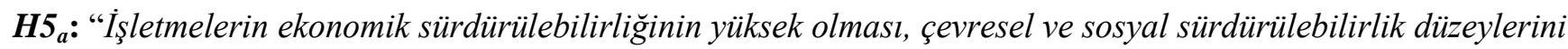
olumlu olarak etkiler", hipotezine ilişkin yapılan test sonucunda; sırasıyla $r=0,514$ ve $r=0,615$ bulunmuştur ( $\mathrm{p}<0,001)$. Böylece $\boldsymbol{H} \boldsymbol{5}_{\boldsymbol{a}}$ hipotezi kabul edilmektedir.

$H_{5}$ : "İşletmelerin çevresel sürdürülebilirliğinin yüksek olmasl, sosyal sürdürülebilirlik düzeyini olumlu olarak etkiler", hipotezine ilişkin yapılan test sonucunda; $\mathrm{r}=0,505$ bulunmuştur $(\mathrm{p}<0,001)$. Elde edilen verilere göre $\boldsymbol{H} \boldsymbol{5}_{\boldsymbol{b}}$ hipotezi kabul edilmektedir.

\section{SONUÇ VE ÖNERILLER}

Araştırma ile Malatya ili 1. ve 2. Organize Sanayi Bölgelerinde faaliyet gösteren 70 işletmeden elde edilen veriler 1şığında, işletmelerin temel özelliklerinin, sürdürülebilir tedarik zinciri yönetimi algılarının ve engellerinin üzerindeki etkisini analiz edilmiştir. Ayrıca; STZY alg1 ve engellerinin, ekonomik, çevresel ve sosyal sürdürülebilirlik performansları üzerindeki etkisi test edilmiştir. Son olarak da işletmelerin, boyutlarıyla (ekonomik, çevresel, sosyal) sürdürülebilirlik performansları arasındaki ilişkiler incelenmiş ve önemli bulgular elde edilmiştir. Analiz sonuçları, çalışmamızın Analiz ve Bulgular bölümünde ayrıntılı olarak verilmiştir.

Katılımcı işletmelerin vermiş oldukları yanıtlara göre, STZY uygulamalarının işletmeler açısından en önemli kazancı "müşteri memnuniyeti" olarak algıladıkları tespit edilmiştir. Onu "ürün kalitesinde artış" cevabı izlemektedir. Ageron vd. (2012) de, yapmış olduğumuz çalışmaya benzer bir araştırma ile Fransız şirketlerinin sürdürülebilir tedarik zinciri yönetimine yönelik algı ve uygulamalarını kullanarak deneysel bir çalışma ortaya koymuştur. Ageron vd. (2012) de çalışmamız ile ulaştığımız sonuca benzer bir şekilde, işletmeler açısından; müşteri memnuniyeti, tedarikçi yeniliği, kalite ve kapasite gibi önemli faydaların, sürdürülebilir tedarik zinciri üzerinde; teslim süresi, maliyet, esneklik ve envanter optimizasyonundan daha olumlu etkileri olduğu sonucuna ulaşmışlardır.

İşletmelerin STZY uygulamaları önünde engel olarak gördükleri en önemli başlık ise "finansal maliyetler" olarak tespit edilmiştir. Katılımcı işletmelerin engel olarak gördükleri ikinci unsur "STZY' ye yönelik faaliyetlerin yatırım getirilerinin yetersiz olduğ u" düşüncesidir. Yine Ageron vd. (2012), çalışmamı ile elde ettiğimiz benzer bir sonuca ulaşarak; "finansal engellerin, STZY üzerinde, finansal olmayan engellerden daha fazla etkiye sahip olduğu" sonucuna ulaşmışlardır. Alman imalat endüstrisinden dört örnek alarak, sürdürülebilirliğin TZY'ye entegrasyonunu mümkün kılan veya engelleyen en önemli faktörler belirlenmeyi amaçlayan Wolf (2011), benzer bir şekilde "sürdürülebilir tedarik zinciri yönetimi entegrasyonu için ek insan kaynaklarına yatırım yapılması ve yeteneklerin/becerilerin geliştirilmesi gerektiği" sonucuna ulaşmıştır.

İşletmelerin, ekonomik sürdürülebilirlik performansının değerlendirildiği sorulara verilen yanıtlara göre, en yüksek ortalama ile "ürü̈n kalitesinde sürekliliğin sağlanması" cevabı birinci sırada yer almaktadır. "Üretim süreçlerinde israfi önleyici tedbirler" ise ikinci sırada yer almaktadır. Çevresel sürdürülebilirlik performanslarının değerlendirildiği bölümde, katılımcıların vermiş̧ oldukları yanıtlara göre, en yüksek ortalama ile "üretim süreçlerinde ortaya çıkan atık miktarını azaltıcı önlemlerin (geri dönüşüm, verimli atık bertarafı v.s.) alınması" cevabı birinci sırada yer almaktadır. İkinci sırada ise "ürünlerin dayanıklılı̆ının ve ömrünün artırılmasına yönelik faaliyetler" gelmektedir. Çevresel sürdürülebilirlik bağlamında en düşük ortalama ile "yenilenebilir enerji kullanımı" son sirada yer almaktadır. Bu sonuca göre, yenilenebilir enerji kullanan katılımcı işletme sayısının, son derece sınırlı olduğu tespit edilmiştir. Sosyal sürdürülebilirlik performanslarının ele alındığı bölümde ise katılımcı işletmeler için en önemli faktör, "adil işçilik, insan hakları ve etik ticaret" uygulamaları olarak kabul edilmiştir. Verilen yanıt ortalamalarına göre, "çalışanların yetenek, motivasyon ve sadakat gibi bireysel yönlerinin desteklenmesi” sosyal sürdürülebilirlik uygulamaları içerisinde ikinci sırada yer almaktadır.

Elde edilen bulgular ışığında, araştırma konusu işletmelerin sürdürülebilirlik uygulamalarının genel ortalamalarını siralayacak olursak; 4,39 ortalama ile "ekonomik sürdürülebilirlik", 4,33 ortalama ile "sosyal sürdürülebilirlik", 4 ortalama ile "çevresel sürdürülebilirlik" uygulamaları izlemektedir. Bu sonuca göre sürdürülebilir üretimin önemli başlıklarından olan çevresel sürdürülebilirlik uygulamalarının son sırada yer alması, işletmelerin diğer boyutlara göre, "yeşil ve temiz" üretime daha az önem verdiklerini göstermektedir.

Literatür ve yapılmış olan benzer çalışmalar dikkate alınarak hazırlanan araştırma modeli çerçevesinde geliştirilen hipotezlere göre, STZY algılarının, işletmelerin temel yapısal özelliklerine göre farklılık gösterdiğini ileri süren $\boldsymbol{H} \boldsymbol{1}$ hipotezinin, yalnızca, alt hipotezlerinden olan $\boldsymbol{H} \boldsymbol{1}_{\boldsymbol{t}}$ hipotezi kabul edilmiştir. Buna göre işletmelerin, ISO 9001 Kalite Yönetim Sistemi Sertifikası' na sahip olup olmama durumlarının, STZY algısı üzerinde anlamlı bir farklılığa neden olduğu kabul edilmektedir. Bu kabulden hareketle, verilen yanıtlar analiz 
edildiğinde; ISO 9001 Kalite Yönetim Sistemi Sertifikasına sahip olmayan işletmeler, 4,75 ortalama ile söz konusu sertifikaya sahip olan işletmelere göre, daha yüksek bir STZY algı düzeyine sahip olduğu kabul edilmiştir. $\boldsymbol{H} \boldsymbol{1}$ hipotezinin diğer alt hipotezleri ise reddedilecektir.

STZY uygulamaları önündeki engellerin, işletmelerin yapısal özelliklerine göre farklılık gösterdiğini ifade eden H2 hipotezinin alt hipotezlerinden; "işletmelerin çalışan sayısına, hammaddeleri tedarik ettikleri pazara ve hammadde tedarik şekline” göre STZY uygulamaları önündeki engellerin dağılımında, anlamlı bir farklılık bulunduğu kabul edilmektedir. Belirtilen alt hipotezlerin dışında kalan hipotezler reddedilecektir. Kabul edilen hipotezlerde tespit edilen anlamlı farklılıklar incelendiğinde; STZY uygulamaları önündeki engel düzeyi en yüksek olan ișletmeler, 3,8 ortalama ile mikro ișletmeler olarak kabul edilmiștir. Onları 3,05 ortalama ile ikinci sırada küçük işletmeler takip etmektedir. Üçüncü sırada 2,99 ortalama ile küçük işletmeler, dördüncü sırada ise 2,06 ortalama ile büyük işletmeler yer almaktadır. Bu verilerden hareketle, işletmelerin istihdam ettikleri çalışan sayıları arttıkça, STZY uygulamaları önündeki engel düzeylerinin azaldığı kabul edilecektir.

H2 hipotezinin, kabul edilen diğer alt hipotezlerinde yer alan anlamlı farklılıklar incelendiğinde; hammaddelerini yalnızca yerel pazardan tedarik eden işletmelerin, STZY uygulamaları önündeki engel düzeyi 3,67 ortalama ile ilk sırada yer almaktadır. Onu ikinci sırada, 3,15 ortalamaya sahip olan, hammaddelerini yalnızca yurtiçinden temin eden işletmeler takip etmektedir. Üçüncü sırada 2,23 ortalama ile hammaddelerini yerel ve yurtiçi pazardan sağlayan, dördüncü sırada 2,76 ortalama ile hammaddeleri yurtiçi ve yurtdış1 pazarlardan sağlayan işletmeler yer almaktadır. Elde edilen veriler sonucunda, işletmelerin hammaddeleri tedarik ettikleri pazarlar çeşitlendikçe ve genişledikçe, STZY uygulamaları önündeki engel düzeylerinin azaldığı kabul edilmiştir.

Üretimde ihtiyaç duyulan hammaddeleri, yalnızca işletmeye ait araçlar ile tedarik eden işletmelerin, STZY uygulamaları önündeki engel düzeyi, 3,74 ortalama ile birinci sırada yer almaktadır. 3,05 ortalama ile yalnızca tedarikçi araçları ile hammadde temini yapan işletmelerin, STZY uygulamaları önündeki engel düzeyinin, ikinci sırada yer aldığı kabul edilmiştir. Böylece, hammadde tedarikini yalnızca işletmeye ait araçlarla veya yalnızca tedarikçi araçları ile sağlayan işletmelerin, STZY uygulamaları önündeki engel düzeyleri, nakliye firmalarının da dâhil olduğu, çeşitlendirilmiş tedarik şekline sahip olan işletmelerin engel düzeylerinden daha yüksek olduğu kabul edilmiştir.

Araştırma sonucunda, işletmelerin STZY algısı ile sürdürülebilirlik performansları arasında anlamlı bir ilişki olduğunu ileri süren $\boldsymbol{H 3}$ hipotezi kabul edilmiştir. Bu sonuca göre katılımcı işletmelerin STZY algısı ile ekonomik, çevresel ve sosyal sürdürülebilirlik performansları arasında anlamlı bir ilişkinin varlığı kabul edilecektir. Elde edilen bulgulara göre, STZY uygulamaları önündeki engeller ile sürdürülebilirlik performansları arasında anlamlı bir ilişki olduğunu kabul eden $\boldsymbol{H} \boldsymbol{4}$ hipotezi reddedilecektir.

İşletmelerin sürdürülebilirlik uygulamalarının boyutları (ekonomik, çevresel, sosyal) arasında anlamlı bir ilişki olduğunu ifade eden $\boldsymbol{H 5}$ hipotezi kabul edilecektir. Bu sonuca göre işletmelerin ekonomik, çevresel ve sosyal sürdürülebilirlik performansları arasında pozitif yönlü ve anlamlı bir ilişki olduğu kabul edilecektir.

Carter ve Rogers (2008), tedarik zinciri yönetimi alanında sürdürülebilirlik kavramını tanıtmak ve tedarik zinciri yönetimi bağlamında ekonomik, çevresel ve sosyal performans arasındaki ilişkileri göstermek için, geniş kapsamlı bir literatür taraması ile kavramsal bir teori oluşturmayı amaçlamışlardır. Çalışma sonucunda "stratejik olarak STZY' i üstlenen firmalar, üçlü alt çizginin, üç bileşeninden (ekonomik, çevresel, sosyal boyutlar) sadece bir veya ikisini takip eden firmalardan daha yüksek ekonomik performans elde etmesi beklenmektedir", önerisini ortaya koymuşlardır. Yapmış olduğumuz araştırma sonucu, doğrulanmış olan $\boldsymbol{H 5}$ hipotezinin bu öneriyi destekler mahiyette olduğu görülmektedir.

Çalışma kapsamında ziyaret edilen işletmelerden, veri toplama esnasında alınan geri bildirimler ve gözlemler dikkate alındığında, katılımcı işletme yöneticileri veya sorumlularının büyük oranda, sürdürülebilir tedarik zinciri yönetimi kavramına yabancı olduğu tespit edilmiştir. Veri toplanan işletmeler içerisinde, yalnızca, büyük işletme sınıfında yer alan bir firmanın, sürdürülebilirlik departmanı oluşturmuş olduğu gözlemlenmiştir.

Araştırma ile katılımcı işletmelerden elde edilen istatistiksel veriler ve geri bildirimler ışı̆̆ında, yenilenebilir enerji kullanan işletme sayısının düşük olduğu tespit edilmiştir. İşletmelerin fabrika binaları ve çevresinde bulunan alanlarında güneş veya rüzgâr enerjisi sistemleri ile elektrik üretimi gibi yenilenebilir enerji sistemlerinden, atık su geri dönüşümü sistemleri gibi çevreci sistemlerden daha fazla istifade etmesi, ekonomik ve çevresel sürdürülebilirliğe doğrudan katkı sağlayacaktır. İşletmelerin yönetici ve çalışanlarının sürdürülebilir ekonomi, çevre ve toplum konularında, hizmet içi eğitim programları oluşturmaları veya bu konuda profesyonel anlamda destek almaları, işletmeler açısından faydalı görülmektedir. 
İşletmeler, yeni teknolojik gelişmelerin 1şığında, Ar-Ge faaliyetlerine daha fazla önem vererek, yenilikçi yaklaşımlar ile tedarik zincirlerini daha sürdürülebilir hale getirebilirler. Malzeme ihtiyaç plânlaması, kurumsal kaynak plânlaması, üretim plânlama ve kontrol, lojistik faaliyetleri, depo uygulamaları ve insan kaynakları vs. gibi konularda, gelişmiş yazılım tabanlı programların kullanımı, işletmelerin tedarik zincirlerinin sürdürülebilir kılınmasına yardımcı olacaktır. Ayrıca işletmelerin, sürdürülebilirliklerini ve rekabet edebilirliklerini koruma adına, dördüncü sanayi devrimi olarak adlandırılan, nesnelerin interneti ve siber fiziksel sistemlere dayalı, akıllı fabrika uygulamalarını hayata geçirecek yol haritalarına sahip olmaları, işletmelerin geleceği için önem arz etmektedir.

Son dönemde yaşamış olduğumuz, küresel çapta cereyan eden ekonomik, çevresel ve toplumsal krizlerin daha öngörülebilir olması için sürdürülebilirlik kavramı üzerinde önemle durulmalıdır. Küreselleşmenin çok daha yakından hissedildiği son asırda, ortaya çıkan krizlerin etkisi, sadece krizin çıktığı merkezi etkilememekte, bizleri küresel ölçekte önlem almaya zorlamaktadır. Bu durum işletmeler, sivil toplum kuruluşları ve devletler arasında, uluslararası ortaklıkların geliştirilmesini beraberinde getirmektedir. Bu noktada, özelde işletmelerin ve genelde uluslararası tedarik zincirlerinin önemi giderek artmaktadır. Tedarik zincirlerinin sürdürülebilir kılınması; tüketici memnuniyeti, kârlılık ve büyüme hedeflerine ulaşılması, ürün kalite standartlarının sağlanması, gıda güvenliği, karbon salınımının azaltılması, su kaynaklarının korunması, geri dönüşüm ve verimli atık bertarafı, haksız rekabetin önlenmesi, toplumsal motivasyonun sağlanması vs. gibi konularda başarıyı beraberinde getirecektir.

\section{KAYNAKÇA}

AGERON, Blandine, GUNASEKARAN, Angappa ve SPALANZANİ, Alain (2012), "Sustainable Supply Management: An Empirical Study”, International Journal Production Economics, S.140, ss.168-182.

AHI, Payman ve SEARCY, Cory (2013), “A Comparative Literature Analysis of Definitions For Green And Sustainable Supply Chain Management", Journal of Cleaner Production, S.52, ss.329-341.

AKGÜL, Urungu (2010), "Sürdürülebilir Kalkınma: Uygulamalı Antropolojinin Eylem Alanı", Ankara Üniversitesi Dil ve Tarih-Coğrafya Fakültesi Antropoloji Dergisi, S.24, ss.134-164.

ARI, E. Sertaç ve ERGIN, Erhan (2018), “Sürdürülebilir İsletme Olma Yolunda Çözüm Önerileri”, Bitlis Eren Üniversitesi Akademik İzdüşüm Dergisi, S.3(4), ss.1-18.

BESKE, Philip, LAND, Anna ve SEURING, Stefan (2014), "Sustainable Supply Chain Management Practices And Dynamic Capabilities in The Food Industry: A Critical Analysis of The Literatüre", International Journal Production Economics, S.152, ss.131-143.

CARTER, Craig R. ve ROGERS, Dale S. (2008), "A Framework of Sustainable Supply Chain Management: Moving Toward New Theory, International Journal of Physical Distribution \& Logistics Management, S.38(5), ss.360-387.

CASTKA, Pavel ve BALZAROVA, Michaela A. (2008), "ISO 26000 And Supply Chains - on The Diffusion of The Social Responsibility Standard", International Journal Production Economics, S.111, ss.274-286.

ÇETINKAYA, Balkan, CUTHBERTSON, Richard, EWER, Graham, KLAAS-WISSSING, Thortsten, PIOTROWICZ, Wojciech ve TYSSEN, Christoph (2011), Sustainable Supply Chain Management, Springer Publisher, Heidelberg - Germany.

GALAL, Noha M. ve ABDUL MONEIM, Ahmed F. (2016), "Developing Sustainable Supply Chains in Developing Countries", 23rd CIRP Conference on Life Cycle Engineering, Procedia, S.48, ss.419424.

GEDİK, Tarık ve ÇiL, Muhammed (2015), "Batı Karadeniz Bölgesinde Yer Alan Orman Ürünleri Sanayi İsletmelerinde Sürdürülebilir Üretim Uygulamaları Üzerine Bir Araştırma", Ormancılık Dergisi S.11(2), ss.1-12.

GOPALAKRISSHNAN, Kavitha, YUSUF, Yahaya Y., MUSA, Ahmed, ABUBAKAR, Tijjani ve AMBURSA Hafsat M. (2012), "Sustainable Supply Chain Management: A Case Study of British Aerospace (BAE) Systems", International Journal Production Economics, S.140, ss.193-203. 
HARMS, Dorli, HANSEN, Erik G. ve SCHALTEGGER, Stefan (2012), "Strategies in Sustainable Supply Chain Management: An Empirical Investigation of Large German Companies", Corporate Social Responsibility and Environmental Management, S.20(4), ss.205- 218.

LEE, Hau L. ve BÍLLINGTON, Corey (1992), "Mananging Supply Chain Inventory: Pitfallsand Opportunities", Solan Management Review, S.33(3), ss.65-73.

ŞİŞMAN, Bilal, DOĞAN, Mesut ve AĞCA, Veysel (2016), “Tedarik Zinciri Yönetimi Boyutuyla Kurumsal Sürdürülebilirlik ve Finansal Performans Illişkisi: BISST Sürdürülebilirlik Endeksinde Yer Alan Firmalarda Bir Araştırma", Bolu Abant İzzet Baysal Üniversitesi Sosyal Bilimler Enstitüsü Dergisi, S.16(1), ss.75-96.

TCHAIKOVSKY, Zulfiya (2017), "The Relationship Between Sustainable Supply Chain Management, Stakeholder Pressure, and Financial Performance", Doctoral Thesis, Walden University, Washington (USA).

TOKER, Kerem (2017), “Tedarik Ağları, Değer ve Sürdürülebilirlik”, İşletmelerde Sürdürülebilirlik Dinamikleri (Ed. Işı1 Mendeş Pekdemir), Beta Yayınları, İstanbul, ss.274-316.

WITTSTRUCK, David ve TEUTEBERG, Frank (2010), "Ein Referenzmodell für das Sustainable Supply Chain Management", Zeitschrift für Management, S.5(2), ss.141-164.

WITTSTRUCK, David ve TEUTEBERG, Frank (2012), "Understanding the Success Factors of Sustainable Supply Chain Management: Empirical Evidence from the Electrics and Electronics Industry", Corporate Social Responsibility and Environmental Management, S.19, ss.141-158.

WOLF, Julia (2011), "Sustainable Supply Chain Management Integration: A Qualitative Analysis of the German Manufacturing Industry", Journal of Business Ethics, S.102, ss.221-235.

WU, Zhaohui ve PAGELL, Mark (2011), Balancing Priorities: Decision-Making In Sustainable Supply Chain Management, Journal of Operations Management, S.29, ss.577-590.

ZAILANI, Suhaiza, JAYARAMAN, Krishnaswamy, VENGADASAN, G. ve PREMKUMAR, Rajagopal (2012), "Sustainable Supply Chain Management (SSCM) in Malaysia: A Survey", International Journal of Production Economics, S.140(1), ss.330-340. 